\title{
New Perspectives on the Political Economy of Great Zimbabwe
}

\author{
Shadreck Chirikure ${ }^{1,2}$
}

Published online: 10 June 2019

(c) The Author(s) 2019

\begin{abstract}
This review draws from old and new archaeological data and takes interpretive flavor from indigenous African concepts to demonstrate that, within a context of local and external interfaces, Great Zimbabwe's political economy was a mosaic rooted more in a mix of seasonally specific, household-based, compositional strategies of production and circulation and less in the redistribution of archaeologically lowfrequency exotics from the Indian Ocean. An ideology based on the hierarchical triad of land, ancestors, and belief in God underwrote custodial rights and extractive powers that at times enabled rulers to access a share of productive, allocative, and circulative activities in their territories. Simultaneously, households and communities freely participated in the economy, often inside and outside state control and influence, demonstrating the individual, collective, mixed, embedded, and capillary nature of the political economy.
\end{abstract}

Keywords Mechanics of production - Collective action · Circulation · Distribution · Surplus · Great Zimbabwe · Capillary nature of political economy · Wealth-inpeople

Shadreck Chirikure

shadreck.chirikure@uct.ac.za

1 Department of Archaeology, University of Cape Town, Private Bag, Rondebosch 7701, Cape Town, South Africa

2 School of Archaeology, University of Oxford, 1 South Parks Road, Oxford OX1 3TG, England 
When dealing with a small sample such as is available for early civilizations, data must be considered within a more contextualized framework if researchers are to understand their significance (Trigger, 2003, p. $\mathrm{x}$ )

\section{Introduction}

As a theoretical and analytical approach to archaeology, political economythe study of social relations based on unequal access to wealth and power-has a relatively deep history and is popular in the Anglophone archaeological tradition (Chacon and Mendoza 2017; Cobb 1993; Earle 1997; Feinman 2016; Haas 1982; Hirth 1996; McIntosh 1999; Roseberry 1989; Smith 2004; Stahl 2004; Yoffee 2005). The approach has been influential in Mesoamerica and Mesopotamia, where scholars of varying theoretical shades, from Marxists to substantivists, have over time explored topics ranging from the importance of hierarchical and heterarchical logics, relations of production, distribution mechanisms, and among others class entanglements and inequality in the political economy of premodern states and urban systems (Crumley 1995; Earle 1987; Ehrenreich et al. 1995; Feinman and Neitzel 1984; Haas 2001; McIntosh 1999; Polanyi et al. 1957; Rowlands 1989; Shennan 1993; Stahl 2004). This makes political economy one of the most successful lenses through which archaeologists examine relations between the economy and politics in prehistoric communities at various scales of sociopolitical organization (Chirikure 2007; D'Altroy and Earle 1985; Friedman and Rowlands 1977; Hirth 1996; McIntosh 1999; Monroe and Ogundiran 2012; Morrison 1994; Pwiti 1991; Redmond 1998; Service 1975; Stahl 2014).

Despite this thematic diversity, archaeological studies of political economy have not remained static over time. Old approaches to political economy, particularly those influenced by Marxist theoretical filaments, tended to couple control of production and labor to account for the evolution of complex societies in regions such as Bronze Age Eurasia within a culture historical and evolutionary perspective (Childe 1950). By the late 1950s, substantivists such as Polanyi (Polanyi et al. 1957) emphasized the contribution of external long-distance trade to the evolution of centralized political forms and operation of premodern political economies in different parts of the world, Africa included (e.g., Dalton 1977; Friedman and Rowlands 1977). Following Wallerstein (1974), world systems theories have focused on the importance of existing relationships and networks of interaction between different areas and regions to document large-scale social networks (e.g., Stein 1998). While political economic theories continue to improve (e.g., Blanton and Fargher 2008; DeMarrais and Earle 2017; Feinman and Nicholas 2012; Stahl 2014), the major limitation of older approaches is that often they dichotomized the political economy into individual variables such as production and distribution without contextually integrating them to provide a comprehensive picture of how societies in different places functioned at different times (Hirth 1996; Feinman and Carballo 2018). Furthermore, the definition of cores and peripheries in approaches that used the "old" world systems thinking was often subjectively made without fully understanding 
local contexts in different world areas (Kohl 1989). And yet, the inhabitants of some regions labeled as peripheries in parts of Asia and Africa (and virtually everywhere) made conscious decisions to be stateless and interacted with the so-called cores in their own ways, demonstrating variability in human strategies across space and time (Scott 2009). This and other limitations precipitated the emergence of newer approaches that explored the mix of strategies employed by societies through collective and individual action to produce, manipulate, mobilize, and allocate resources in different places and at different points in time (Blanton and Fargher 2008; DeMarrais and Earle 2017; Feinman and Carballo 2018; Feinman and Nicholas 2012; Hirth 1996; Smith 2004). These newer models that are based on the examination of the local context within a broader perspective reject the bifurcation of control of political economies into monolithic categories such as command based or decentralized and instead view them as a mix of strategies, collective action included, that could be adopted by households in state and nonstate societies alike (e.g., Chirikure 2018).

By far, the application of the concept of political economy to African archaeology lags behind global trends and, in some cases, is still glommed to older theories whose utility has been questioned for other regions such as Mesoamerica. Forays into the topic of African political economy have been limited to individual aspects such as external long-distance trade and exchange that were assumed to have stimulated the evolution of sociopolitical complexity and early states (Caton-Thompson 1931; Garlake 1973; Huffman 1972; Kusimba et al. 2017; McIver 1906; Pwiti 1991; Wood 2000; but see Hirth 1996; Stahl 2004 for critiques). In a landmark publication, McIntosh (1999, and contributors to the volume) argued for the necessity of profiling local concepts in studying African political economies and perspicaciously revealed that the main theories used to explain economic processes in precolonial Africa were derived from older approaches adopted from other world areas, such as Polynesia and Mesopotamia, without much calibration to the local context (e.g., Berry 2007; Chirikure et al. 2017a; Guyer 2004; Guyer and Belinga 1995). Consequently, adherence to older models of political economy, which have been shown not to work in prehispanic Mesoamerica and elsewhere (Blanton and Fargher 2008; Feinman and Carballo 2018; Feinman and Nicholas 2012; Hirth 1996), continues to produce elite-centric and exotics-fueled models of political economies in Africa south of the Sahara (Chirikure et al. 2014; Klehm 2017; McIntosh 1999).

Not surprisingly, attention has slowly percolated around contextual approaches that combine local and externally driven concepts but without privileging one over the other (Chirikure et al. 2014; Guyer and Belinga 1995; Klehm 2017; Robertshaw 1999; Stahl 2014). This marshaled the research to focus on approaches that consider the local specifics first, before considering interfaces with the external, to map the variability of historical trajectories, historical contingencies, and the combination of elements that arrive at similar-looking but operationally different results at a broad scale of analysis (Blanton and Fargher 2008; Feinman and Nicholas 2012; Guyer 2007; Klehm 2017; McIntosh 1999; Moffett and Chirikure 2016; Stahl 2015). My goal in this contribution is to critically engage the socially embedded elements of the political economy of Great Zimbabwe, such as the mechanics of production, workings of circulation, and consumption of commodities, through African-centered conceptual lenses. Simultaneously, I seek to reengage critically broader comparative 
studies and theoretical innovations elsewhere to reposition Africa in global studies (Blanton and Fargher 2008; DeMarrais and Earle 2017; Feinman and Nicholas 2012; Hirth 1996; Stahl 2014). While I advocate the importance of the local context, such an effort inevitably focuses on the richness of African examples, drawing on local conditions and history in addition to broader discussions, to demonstrate similarities and variabilities of human experiences across regions at multiple but nested scales of enquiry.

Framed within the idea of political economy as a holistic and integrated approach to explore production, circulation/distribution, consumption, inequality, and other relations in society, my goal is to offer a new interpretation of the political economy of Great Zimbabwe as a city, a capital, and a state. I show that Great Zimbabwe had transient production locations and possessed no fixed redistribution centers such that circulation unfolded on recursive scales. Rather, it developed a mosaic political economy in which production and circulation were embedded in compositional strategies (e.g., cooperative, based on differences in skills, knowledge) essential for meeting collective and individual needs at all levels-household, village, district, province, capital, state-within a multidimensional environment conditioned by local particularities (Chirikure 2014; McIntosh 1999; Mudenge 1988; Stahl 2004). Within such a constantly shifting mosaic, the global and the exotic were only incorporated, appropriated, and recontextualized to the extent that they intersected with local political economic logics (e.g., Norman 2015; Prestholdt 2008; Stahl 2015). From a cross-regional comparative point of view, I argue that the political economic processes associated with Great Zimbabwe and related polities were driven more by local dynamics and minimally by global interactions that brought few exotics that were accessible to all, regardless of class (Chirikure 2014). When fitted into local economies, such exotics and global commodities became local and acquired local meanings in rituals, aesthetics, personhood, status, trade, and exchange, among others, which limited the thresholds they could cross in the receiving communities (Barber 2007; Berry 2007; Chirikure 2014). This recursive bottom-up (local to global) approach is not a denial of the contribution of global processes in shaping African history; it is a demonstration that people in different parts of the world have their own histories that coalesce into a globally shared past.

\section{Great Zimbabwe: A Brief History of the Site and Previous Treatments of the Political Economy}

Great Zimbabwe (Fig. 1) is a large, 720-ha multibuilding settlement that functioned as the capital of a 50,000- $\mathrm{km}^{2}$ territorial state of the same name (Garlake 1973; Huffman 2007; Kusimba et al. 2017; Pikirayi 2001). It is made up of drystonewalled buildings - the Hill Complex, the Great Enclosure, the Valley Enclosuresthat are flanked by smaller satellite areas such as Chenga and Nemanwa (also within the 720 ha). Among the drystone built areas are extensive unwalled settlements, marked by house floors and contiguous domestic middens. Great Zimbabwe is one of the many similar sites known in southern Africa. An unrestricted application of older Childean theories was previously used to suggest that the Great Zimbabwe 


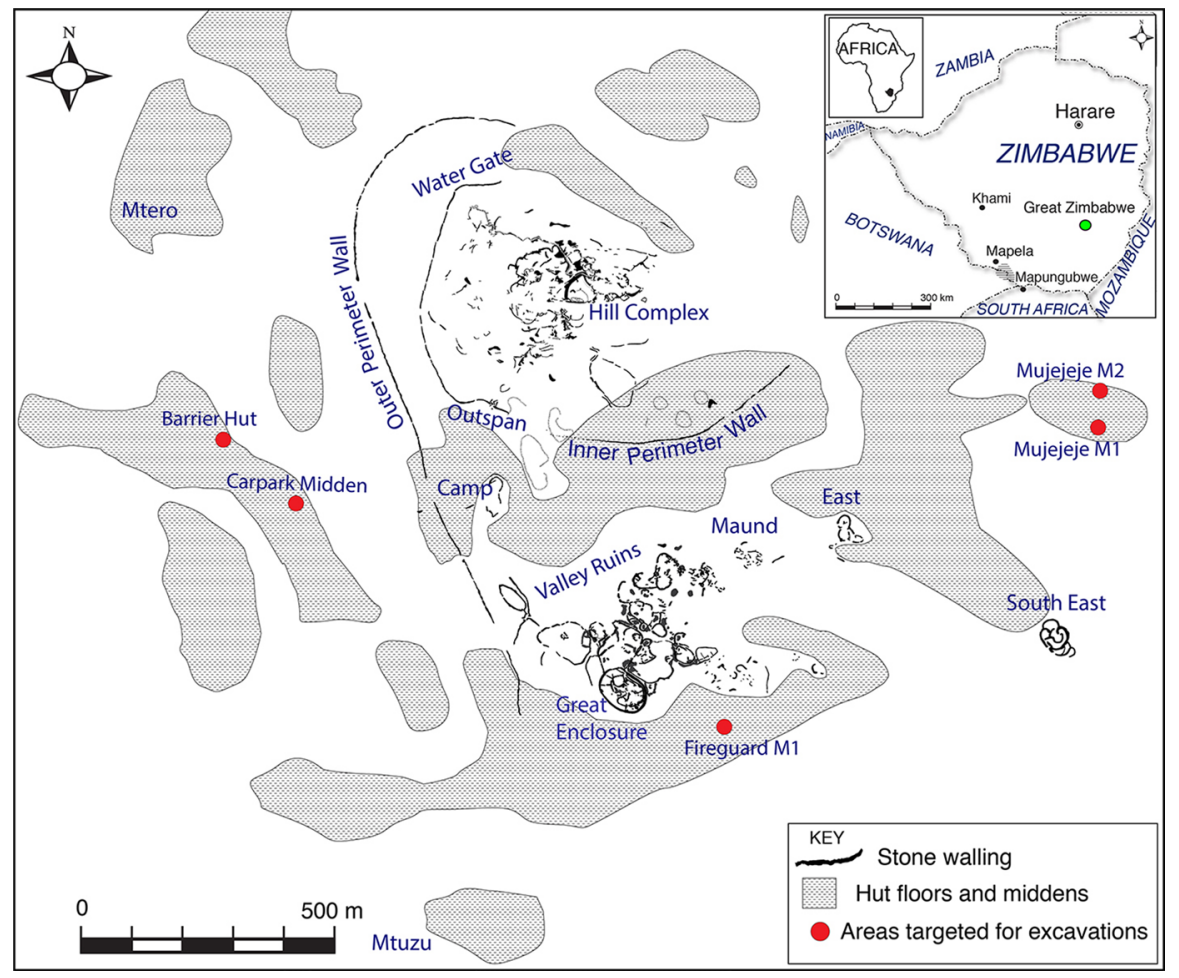

Fig. 1 The main constituent parts of Great Zimbabwe and its location on the African continent.

state was very expansive, covering thousands of kilometers, from the Indian Ocean to the Kalahari Desert (Garlake 1973). However, it is possible that multiple states coexisted in this wide region; the limited nature of research to date makes it difficult to identify boundaries of the Great Zimbabwe state and those of coeval entities (Chirikure et al. 2012).

Locally known for as long as it has existed (Fontein 2006), Great Zimbabwe was brought to the attention of the Western world in 1871 by Karl Mauch, who also looted a number of objects from the site. To some Westerners, particularly those who believed in African incapacity, Great Zimbabwe was a unique architectural masterpiece that could have been built only by "advanced" exotic people, such as Hamites or Semites (Bent 1896; Hall 1905). Since the endeavors of Bent and Hall were sponsored by Cecil John Rhodes, their findings underwrote a wider colonialist ideology that later spurred colonial administrators who set the tone, to this day, for the way that archaeology is conducted and interpreted in southern Africa (e.g., Hall 1990). Bent and Hall's theories stimulated a highly polarized debate that pitted statesponsored amateur archaeologists, who stolidly argued that Great Zimbabwe was foreign (Bent 1896; Hall 1905), against professional archaeologists, who supported a local origin (Caton-Thompson 1931; Garlake 1973; McIver 1906). The destructive nature of Bent and Hall's antiquarian activities, and their passion for gold and exotics, is well known (Garlake 1973; Hall 1990; Mahachi and Ndoro 1997; Matenga 
2011). By the 1960s and 1970s, professional archaeologists (all expatriates) confirmed that Great Zimbabwe was built by local people (Garlake 1973; Summers et al. 1961), but they still marginalized locals from the production of archaeological knowledge while simultaneously fixating on the site because of its links to gold production (Fontein 2006; Matenga 2011).

Established by Summers et al. (1961), the sequence of occupation at Great Zimbabwe has five phases (Fig. 2), the first of which housed first-millennium farmers. Periods II to V (AD 1000-1900) are related to a succession of builders and users of Great Zimbabwe, generally believed to be local Shona people (Chirikure et al. 2017b). The sequencing of Great Zimbabwe has, however, not been without material errors and misunderstandings (Chirikure et al. 2013). Of concern is that, in citing the absence of imported ceramics that postdate AD 1450 from the Hill Complex, Garlake (1973) pegged the flourishing and abandonment of Great Zimbabwe to AD 1200-1450. And yet, further research at the

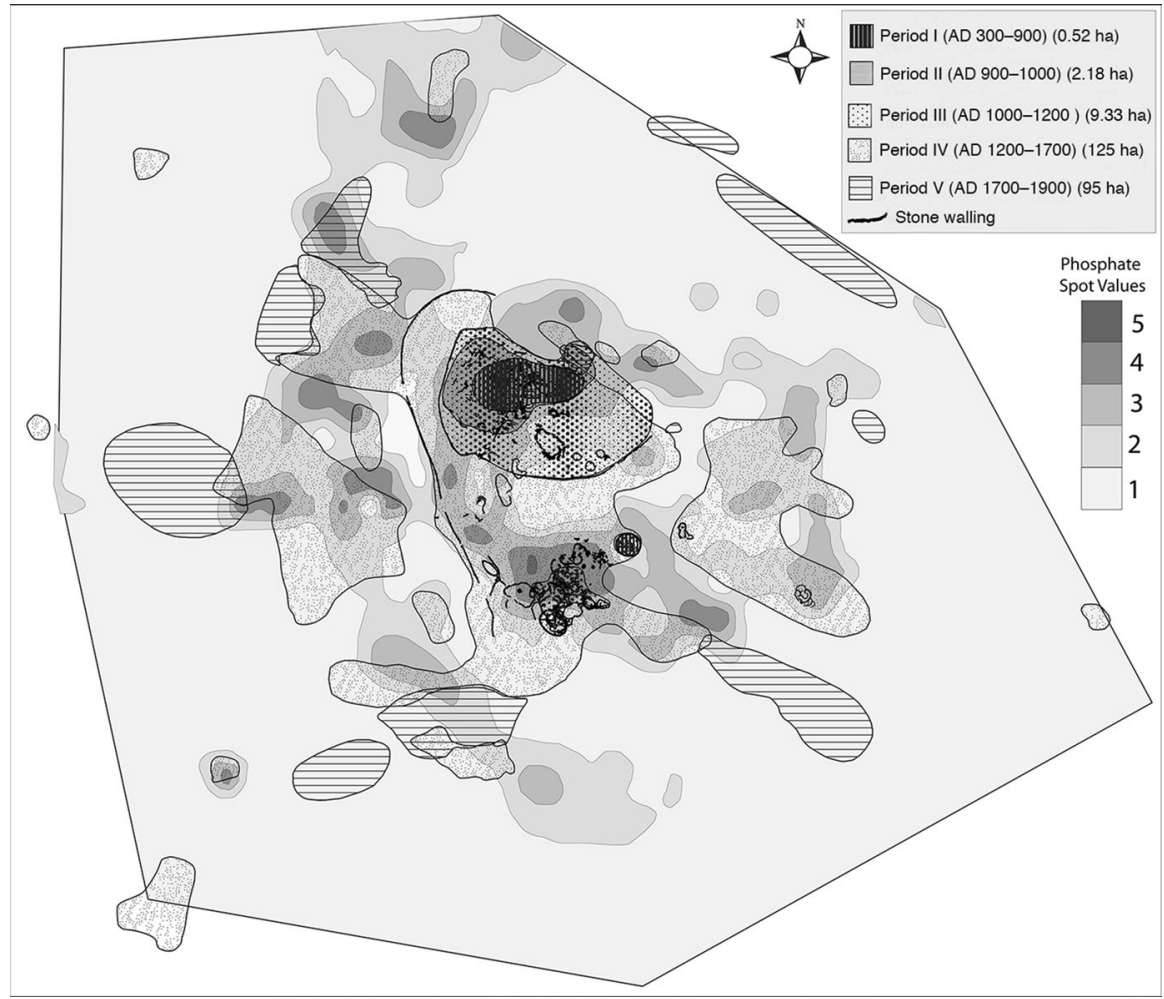

Fig. 2 Different occupational phases of Great Zimbabwe and their spatial and temporal distribution (based on data from Chirikure et al. 2017b, c; Sinclair et al. 1993; Sinclair and Petrén 2010). The density of occupation was measured through drilling cores and measuring phosphate values of the cores (spot values) to develop a proxy for density of human activity (Sinclair et al. 1993). The darkest shades with a value of 5 correspond to the highest density of activity; the lightest shades with phosphate values of 1 indicate minimal levels of human activity. 
site (e.g., Collett et al. 1992) recovered blue on white Chinese porcelain from the Valley Enclosures dating to the 16th century, revealing that the entire town was not abandoned at the same time. Additional work supports this view, showing that different settlements within the 720 ha were capitals that rotated power (Beach 1998; Chirikure and Pikirayi 2008; Chirikure et al. 2017b; Sinclair et al. 1993).

Until recently, attempts to refine the chronology of Great Zimbabwe were hampered by a sparsity of radiocarbon dates (23 radiocarbon dates for 720 ha). Of particular concern was that almost all these dates (barring a few, see Huffman and Vogel 1991) came from walled settlements. This motivated me to lead new research, targeting primarily unwalled settlements on the western side around the current-day car park, the unwalled settlements about $200 \mathrm{~m}$ east of the Great Enclosure, and unwalled homesteads on the eastern side adjacent to a famous quartz vein known as Mujejeje (Chirikure et al. 2017b, c). The doubling of existing radiocarbon dates showed that most unwalled settlements were occupied post-AD 1450, with settlement persisting into the 17th century. An analysis of historically datable imports from the same excavations, and a study of unpublished legacy collections in the Great Zimbabwe Conservation Center, revealed Khami-type glass beads (AD 1450-1650) and a ceramic ndoro (imitation of a conus shell made by the Portuguese post-AD 1500; Ellert 1984). Based on this new chronological information, the AD 1450 cutoff date does not fully capture what was going on at Great Zimbabwe, a city that ebbed and flowed well into the 17th century. Despite problems with reliability, oral traditions relate that local groups such as Nemanwa and Mugabe lived in and around Great Zimbabwe between the late 17 th and 19th centuries (Fontein 2006). With this chronology highlighting cycles of expansion and contraction (see Fig. 2), we need new narratives on the interpretation of various elements of the site, the political economy included.

Against this background, what do we know about the political economy of Great Zimbabwe? A review of archaeological literature exposes the absence of comprehensive studies of the political economy of the site and the state that it controlled. That is not to say that archaeologists and allied specialists never examined individual elements of the political economy of Great Zimbabwe. Far from it, over the course of the 20th century and beyond, trade and exchange, prestige goods, religion, and ideology were molded into general theories (now old) to account for the rise and collapse of Great Zimbabwe and related states (e.g., Beach 1980; Caton-Thompson 1931; Garlake 1973; Huffman 1974, Phimister 1974a; McIver 1906; Sinclair 1987; Pikirayi 2001; Pwiti 2005). As a consequence, the functioning of the political economy was grossly oversimplified, based on old models derived from Polynesia and elsewhere that have no consonance with local African concepts and knowledge (e.g., Chirikure 2014; McIntosh 1999; Stahl 2014). Understanding the political economy of Great Zimbabwe using local concepts generates new knowledge that enables comparisons with other regions in the world to articulate cross-cultural variation (Trigger 2003), even if the patterns on the ground might look similar. 


\section{Crafting the Political Economy of Great Zimbabwe: A Critique of Sources of Information}

Any study of the political economy of Great Zimbabwe inevitably builds on the nature of available sources of information, their resolution, their chronological reach, and ultimately their reliability for studying the economic processes. The study of material remains through archaeology is one such source of information. There exists an archive of objects that accumulated from archaeological work performed from the late 19th century to the present. The archive varies in quality and utility because of legacy issues such as varying standards of excavation and documentation through time (Chirikure et al. 2017b). Then there are sites themselves such as Great Zimbabwe and related spaces on the broader landscape. A consideration of Great Zimbabwe between the late 19th and early 20th centuries reveals amenities, such as a golf course, that were constructed with no prior impact assessment of the unwalled sections mostly on the western and northwestern areas of the site. Also, some sections of the major enclosures of Great Zimbabwe were rebuilt over the course of the 20th century. Meanwhile, archaeological research in Great Zimbabwe's surrounds is very poor, to the extent that the boundaries of the state are unknown. Any engagement with the archaeology of Great Zimbabwe must be alert to these taphonomic processes and gaps in knowledge.

Oral histories collected from Shona elders living around Great Zimbabwe from the early 20th century onward (e.g., Mtetwa 1976) are another source of interpretive analogies. The major limitation of the oral traditions collected by Mtetwa and others is that they were derived from people who are culturally related but not directly connected to Great Zimbabwe. Other available historical sources include a suite of documentary sources, including fragmentary Portuguese-written documents relating to the northern Zimbabwe-based Mutapa state (AD 1450-1900). The Mutapa kingdom is believed to have a direct cultural and genetic connection with Great Zimbabwe (Pikirayi 2001). Incomplete and biased as they sometimes are, the Portuguese documents contain useful information on the political, social, cultural, and economic life of groups now known as Shona. However, the utility of Portuguese documentary sources is diminished by the fact that they do not directly refer to Great Zimbabwe (see Beach 1998 for a detailed discussion). When carefully used to build comparative analogies (sensu Stahl 1993), oral and documentary sources are profoundly important for interpreting the past.

Ethnographies collected by travelers, missionaries, explorers, early colonial administrators, and anthropologists between the late 19th and late 20th centuries are yet another source of information for analogies to study the political economy of Great Zimbabwe. However, ethnographies also have their own problems. The imposition of colonial rule often divided populations into questionable "tribes" that previously did not exist (Chimhundu 1992; Makoni 2013). The division of groups now known as Shona into Karanga, Zezuru, Ndau, etc., was a dubious colonial invention by the Southern Rhodesian Missionary Conference that created groups who did not previously identify with these labels (Chimhundu 1992). This 
limits the utility of such inventions as valid structures for historical study (Kopytoff 1987; Ranger 1983; Stahl 1993; Vansina 1989).

Because of the fragmentary nature of the archaeological record, analogies drawn from ethnographic and historical sources are a fundamental interpretive tool for exploring the political economy of Great Zimbabwe. This approach was adopted by Huffman (1996), who developed, via analogy, a synchronic model for reading the use of space; for the duration of occupation, he allocated the Western Enclosure on the hill to the king, the Valley Enclosures to the queens, and initiation rites to the Great Enclosure. Huffman was sharply criticized for a somewhat fast and loose use of analogies, and critics argued that his interpretation downplayed the dynamism of practice through time (e.g., Beach et al. 1997; Lane 1994-1995; Stahl 1993). Furthermore, because use and function are correlated, Huffman's model created the expectation that the Valley Enclosure would yield material culture consistent only with royal wives, while the Great Enclosure would produce objects consistent with initiation. And yet, this expectation is not met; recent work has uncovered crucibles for working metal, slag, and other activities associated with metalworking, an activity generally reserved for men (Bandama et al. 2016, 2017; Chirikure and Pikirayi 2008). These instances where leads from ethnography do not converge with those from archaeology should be considered as evidence of variation in practice through time (Guyer 2007; Stahl 1993).

Given that analogies are unavoidable in archaeology, scholars have developed ways of improving their utility (Lane 2005; Stahl 1993; Wylie 1985). Stahl (1993) emphasized that a distinction must be made between illustrative and comparative analogies. Illustrative analogies are used to build hypotheses that are as yet unassessed (or assessable) in relation to archaeological evidence (Stahl 1993); evidence of practices and ideologies in later periods remains working hypotheses in the absence of convergent evidence from earlier periods. In the crosshairs is the value of comparative analogies that are concerned with assessing the "fit" between an analogue and the archaeological context, notwithstanding the relevance criteria. We gain insight into points of convergence as well as dissimilarities between the source (ethnographic and historical) and the subject (archaeological contexts) (Stahl 1993), thereby enhancing our ability to explore change through time.

The approach I take combines the use of illustrative and comparative analogies (sensu Stahl 1993; Wylie 1985). I present evidence of practice from the archaeological contexts, followed by illustrative ideas from the source, and then a detailed comparison of the interfaces, similarities, and differences between source and subject and their implications for exploring the dynamism of practice over time.

\section{Defining Concepts: Production, Circulation/Distribution, Surplus, and Consumption}

The most profound elements of political economies are the interrelated and socially embedded variables of production, circulation/distribution, and consumption. Production is the process of acquiring raw materials and transforming them, through the application of labor (including knowledge, skills) and energy 
into finished products (Costin 1991). A simultaneously social and technological process, the organization of production varies from context to context. A number of variables are essential for understanding the organization of production in state and nonstate societies, including the presence or absence of specialization (attached or independent), scale, and intensity of production (Brumfiel and Earle 1987; Chirikure 2007; Cobb 1993; Rice 1981). Specialization involves a system in which producers depend on extra-household exchange relationships at least in part for their livelihood, and consumers depend on such relationships for the acquisition of goods they do not produce themselves (Costin 1991). Sometimes, specialists form a specific social segment because of their skills and coveted knowledge (technical and ritual), which may attract to them followers who are then converted into "wealth-in-people" (Guyer and Belinga 1995). Depending on context, specialization may be full-time or semi-full-time (Rice 1981, p. 220), attached or independent (Brumfiel and Earle 1987), or a mix of all these factors (Costin 1991). This implicates the differentiation of labor within and between tasks and crafts, and the creation of conditions for producing commodities that, as surplus or not, end up circulating through mechanisms such as trade and exchange (Morehart and De Lucia 2015).

Attached specialists produce goods for authorities or elites who typically control both the production and circulation of commodities for their own benefit, thereby creating social and economic inequality (Costin 1991). In contrast, independent specialists normally control their production and its distribution for their own ends (Cobb 1993). Often, they may have paid taxes and rent as required (Chirikure 2014; Mudenge 1988). Generically, attached specialists are mostly associated with hierarchically organized societies, while independent specialists are associated with flatter, less hierarchical societies. However, a mix of independent and attached specialization may be found in state-level societies as well (e.g., Mudenge 1988). Archaeologically, specialization is identifiable by the scale, intensity, and concentration of production remains and, by inference, the quantities of output produced. For example, iron production systems in West Africa from AD 1000 onward often produced thousands of tons of iron slag and associated debris (De Barros 1988). In central West Africa, Sukur annually produced an estimated 60,000 iron hoes that were traded to Bornu (David and Sterner 1997). By comparison, there are only scatters of debris on the landscape and no megamiddens in southern Africa. Production, it seems, was concentrated in one place or dispersed on the landscape (Chirikure 2015; Feinman and Nicholas 2012). Depending on context, concentration and dispersion may, however, produce similar outcomes such as surplus and specialization. In some contexts, specialization may stifle individual creativity by promoting standardization-that is, an increased uniformity in manufacturing techniques, accompanying an increased similarity of the final product (Costin 1991; Rice 1981). Within a political economy, specialization may have many combinations and permutations and could be parttime or full-time. These labels incorporate a wide range of ways for organizing production and labor in both stratified and nonstratified societies (Beach 1974; Brumfiel and Earle 1987). However, the definition of these descriptors and the expression of behaviors they represent are situational and culturally specific (Chirikure 2014). Generalizing their applicability everywhere, all the time, does not tell us about 
variability in strategies of everyday life at cross-cultural scales and unnecessarily hinders a contextual study of production in varied contexts.

Between production and consumption lies output, which may be for individual, household, or community use. Part of the output, particularly beyond individual, household, or consumption needs, is often treated as surplus-a relative concept defined broadly as material resources that are reserved or mobilized apart from the existing functional demands a given social unit imposes on its economy (Morehart and De Lucia 2015; Pearson 1957). According to Hirth (1996, p. 221), surplus mobilization may be associated with shifts in the social fabric that transform the ways things are produced, consumed, and mobilized. The mobilization of surplus goods and labor to finance ritual events in differently organized societies stimulated production through collective action and cooperation and, sometimes, created dependencies and systemic changes in social fabrics (Friedman and Rowlands 1977; Morehart and De Lucia 2015). This point is well illustrated by Norman (2015), who argued that Huedan rulers in Benin in the 17th and 18th centuries were able to employ persuasive strategies to stimulate collective action (sensu Blanton and Fargher 2008) in the political economy and to increase the number of followers who were converted into wealth-in-people (sensu Guyer and Belinga 1995). The Huedan political economy disintegrated as elites shifted their behavior from collective action and reciprocity to the individualized accumulation of commodities obtained through the trans-Atlantic trade (Norman 2015, see also Kopytoff 1987). This underscores the observation that the practical and institutional context within which things are created, thought about, and valued is a dynamically situational and transformational process (Chirikure 2014; Guyer 2007; Stahl 2015).

After production-with or without relative surplus-distribution was essential for allocating and reallocating, and for circulating and recirculating commodities from the social units that produced them to those that consumed them. Circulation was achieved in multiple ways, including alternative forms in which goods and services circulated at individual and societal levels. These include trade and exchange, gifts, taxation, raiding (Mudenge 1988). While trade and exchange could be unsystematic, they were often organized and institutionalized with permanent or shifting distribution and redistribution centers such as marketplaces (Guyer 2007). Itinerancy, involving traders moving from area to area, also was a well-developed system of circulation via trading and exchanging by different groups in parts of Africa (e.g., post-AD 1000, Soninke and Hausa peoples in West Africa; post-AD 1600, Tsonga and Njanja people in southern Africa) (Chirikure 2017). Intermediaries also facilitated the circulation of commodities from producers to consumers with variable amounts of gain (Mudenge 1988). In general terms, exchange is much broader than profit-oriented trade and includes the reciprocal exchange of goods through mechanisms such as gifts, tribute payments, piracy, and even marriage alliances (Cohen 1965). In most African communities, barter-the direct exchange of goods and services without the use of a medium of exchange such as currency-often had both practical and symbolic significance. More importantly, however, the value and gains from trade and exchange transactions in Atlantic West Africa between the 15th and 19th centuries were neither static or fixed but situational and marginal (Berry 2007; Guyer 2007). 
What, then, is the optimal way to identify the circulation of goods and services archaeologically? From both theoretical and practical points of view, the presence of goods and materials manufactured in one region, when found in another, with no production evidence, suggests trade and exchange (Renfrew 1975). Nonetheless, it is essential to exercise extreme caution before attributing all seemingly exotic materials such as a single glass bead, a piece of Chinese celadon, or a fragment of Islamic fritware to trade, even in regions with no productive capacity of their own, since they may have been exchanged as gifts (Chirikure 2014). Even so, there are instances when commodities and services as well as gifts and tribute were exchanged between areas with production capabilities of their own. Furthermore, contact often promotes subsequent imitation and innovation, resulting in stylistically similar objects such as pottery and trinkets being independently made in a wide area through a relay of ideas (Chirikure 2017). All this points to the complexity of circulation in archaeology, even after careful contextual study.

The capillary nature of the political economy in regions such as northern Zimbabwe in the 16th to 19th centuries allowed goods and services in the Mutapa state to be circulated by anybody, anywhere, on a semi-, part-time, and seasonal basis, or a full-time, all-year-round basis, as conditioned by the prevailing situation (Mudenge 1988). Apart from facilitating goods changing hands, circulation stimulated innovation and imitation through culture contact and other forms of interaction (Chirikure 2018). The idea of circulation is essential because it takes away the need to categorize trade and exchange into binaries, such as internal versus external, long-distance versus short-distance, and luxury versus necessity. This is important because the circulation of goods and services, regardless of motive, was often nested and blended together (Chirikure 2017; Morehart and De Lucia 2015; Stahl 2015).

The circulation of exotics strongly implicates the concept of the "prestige goods" economy in understanding the recursive operationalization of external exchange in the political economy. According to Ekholm (1978), since prestige goods were valued by society at large in selected contexts in regions such as Indonesia, Melanesia, and Africa, the individuals controlling their circulation converted that position into high-social status through overt ownership. However, prestige is "in the eye of the beholder"; it is culturally and contextually specific and is not associated just with exotics (Chirikure 2014). Possession of local resources such as land and cattle also was a source of prestige in the historical Luba state of central Africa (Vansina 1999), the Mutapa state (AD 1450-1900) in northern Zimbabwe (Mudenge 1988), and 19th-century Buganda in Uganda (Kodesh 2010), where their liquidation created social obligations (wealth-in-people) that sometimes made them more valuable than exotics (Mudenge 1988).

As a source of social power, ideologies - a combination of overarching ideas and configuration of practices-operating at different cross-societal levels (DeMarrais et al. 1996) affect attitudes to production, surplus accumulation, circulation, and consumption, which often produce different outcomes, even if the outward expressions look the same (McIntosh 1999). For example, among the 16th-century Shona of Zimbabwe, kings and chiefs, by divine right, owned all the land and resources (Beach 1980; Lan 1985; Moore 2005; Mudenge 1988). This religious-sanctioned ownership empowered them to exact a share of commodities produced and circulated 
on their land without either owning or controlling the means of production and circulation. It also spared kings the logistics associated with controlling output from various production activities scattered throughout their territories and, at the same time, afforded them goods that were converted to wealth-in-people (Mudenge 1988). As elsewhere, ideologies were materially expressed through feasts, ceremonies, symbolic objects, and public buildings (DeMarrais et al. 1996).

While the past and the present are clearly not the same, the elaboration of these concepts and their ideological contours in controlled contexts generate possibilities on which an understanding of the mechanics of production, circulation/distribution, and consumption within the political economy of Great Zimbabwe may be hinged. Ultimately, it is hoped that the outcome may unlock profound lessons relating to the culturally specific nature of political economies globally.

\section{Evidence of Production and Circulation at Great Zimbabwe and Beyond}

In presenting the evidence of production and circulation at Great Zimbabwe itself, and in the wider territory under its control, I consider that the political economy operates at the interface of multiple scales (local, regional, and external), that there are limitations imposed by the available data, and that African concepts offer potential grist.

\section{Craft and Economic Production}

\section{Metallurgy}

Evidence of primary production and secondary processing of ferrous and nonferrous metals and alloys is present in earlier (c. AD 1000) and later (c. AD 1600-1700) homesteads dispersed across Great Zimbabwe. Remnants from the smelting of iron, copper, and tin, such as partially reduced ores, slags (Fig. 3), and broken tuyeres, recovered throughout Great Zimbabwe attest to metal smelting (Bandama et al. 2016). The debris from the secondary working of metal, such as smithing slag, crucibles, wire draw plates, and casting spills, and even finished objects are often recovered in the same contexts with smelting remains (Bandama et al. 2017; CatonThompson 1931; Miller 2002). The crucibles (Fig. 4) were used to melt gold, copper, bronze, and brass.

Finished utilitarian and decorative iron objects that range from hoes, spears, axes, and arrowheads to more decorative bangles and bracelets also were recovered from across the site, from Periods II to IV, in both walled and unwalled areas. The Carpark Midden yielded a remnant of a musical instrument in the form of a thumb piano (mbira key). While most iron objects were likely made at the site, one category of musical instrument-iron gongs-was recovered from the Valley Enclosures and elsewhere. Ethnographically, the distribution of iron gongs is mostly known in regions north of Zambezi, in central Africa (Cline 1937; Vansina 1969). 
Fig. 3 Iron smelting slags from Great Zimbabwe.

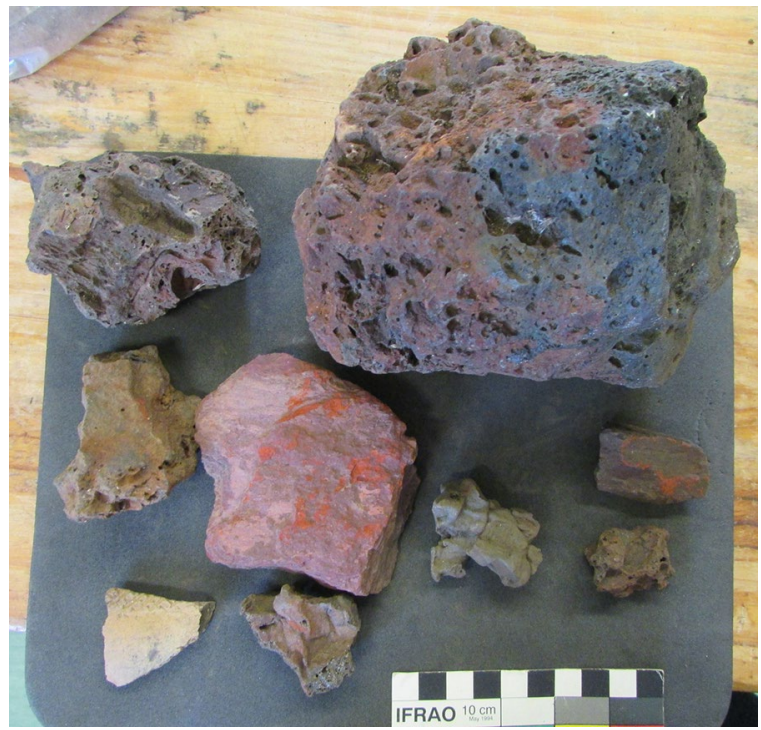

Fig. 4 Gold melting crucibles from the Fireguard Midden, Great Zimbabwe.

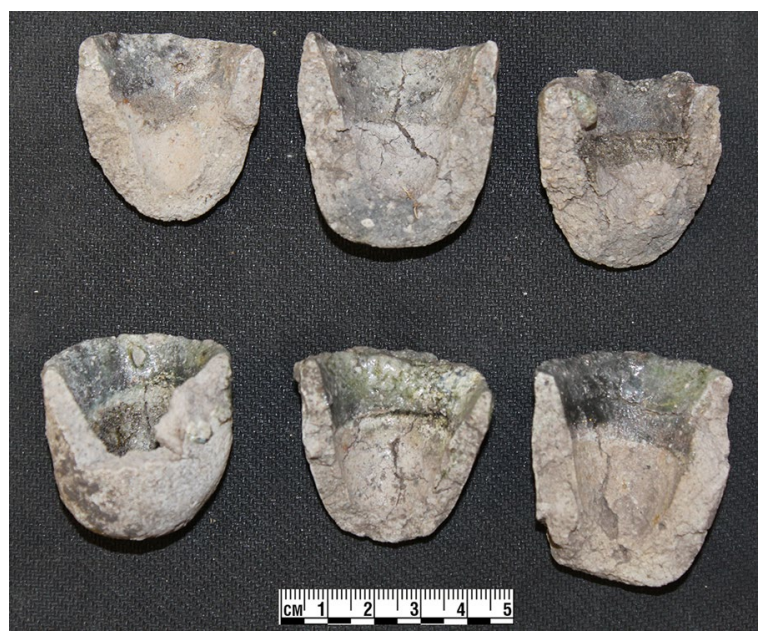

Other objects with a stylistic connection to central Africa include X-shaped copper ingots that have been recovered from Great Zimbabwe and other places south of the Zambezi (Swan 2007).

Decorative and ornamental copper, bronze, and, to a limited extent, brass objects also have been recovered from homesteads across the site. In addition, ceremonial bronze spearheads were uncovered at the Hill Complex and tin ingots on flats near Camp Ruin (Miller 2002). Gold objects—sheets, beads, and a wide assortment of decorative pieces-were recovered from both walled and unwalled areas; they were used for the same purpose as their copper and bronze counterparts. Unfortunately, most of the gold objects were looted in the late 19th and early 20th centuries, making 
it difficult to estimate the quantities of gold at the site (Garlake 1973). Because zinc, one of the key constituents of brass, was not worked in precolonial southern Africa (Miller 2002; Summers 1969), the brass objects likely came from an external source. Great Zimbabwe received finished metal objects at the same time that they made others. Overall, the distribution of metal working follows the chronological evolution of the site. In areas that were coeval, the evidence was not restricted to specific homesteads in both the walled and unwalled areas. Given the episodes of expansion and contraction of the site, there appears to have been continuity in household metallurgical practices and the use of metallurgical symbols and status icons at the site through space and time.

Where did Great Zimbabwe obtain its ores for metal production? Was all metal locally produced and acquired? The site is located within variable distances of exploitable sources of iron, copper, tin, and gold (Fig. 5). Iron mines are present in hills to the east, 5 to $10 \mathrm{~km}$ away from the site (Mauch 1874). Gold deposits are present in metamorphic rocks approximately $10 \mathrm{~km}$ to the north, toward Masvingo (Summers 1969). It is possible that other gold deposits in Mashava (c. 50 $\mathrm{km}$ west) and Mberengwa (c. $150 \mathrm{~km}$ southwest) also were exploited (Fig. 5). For

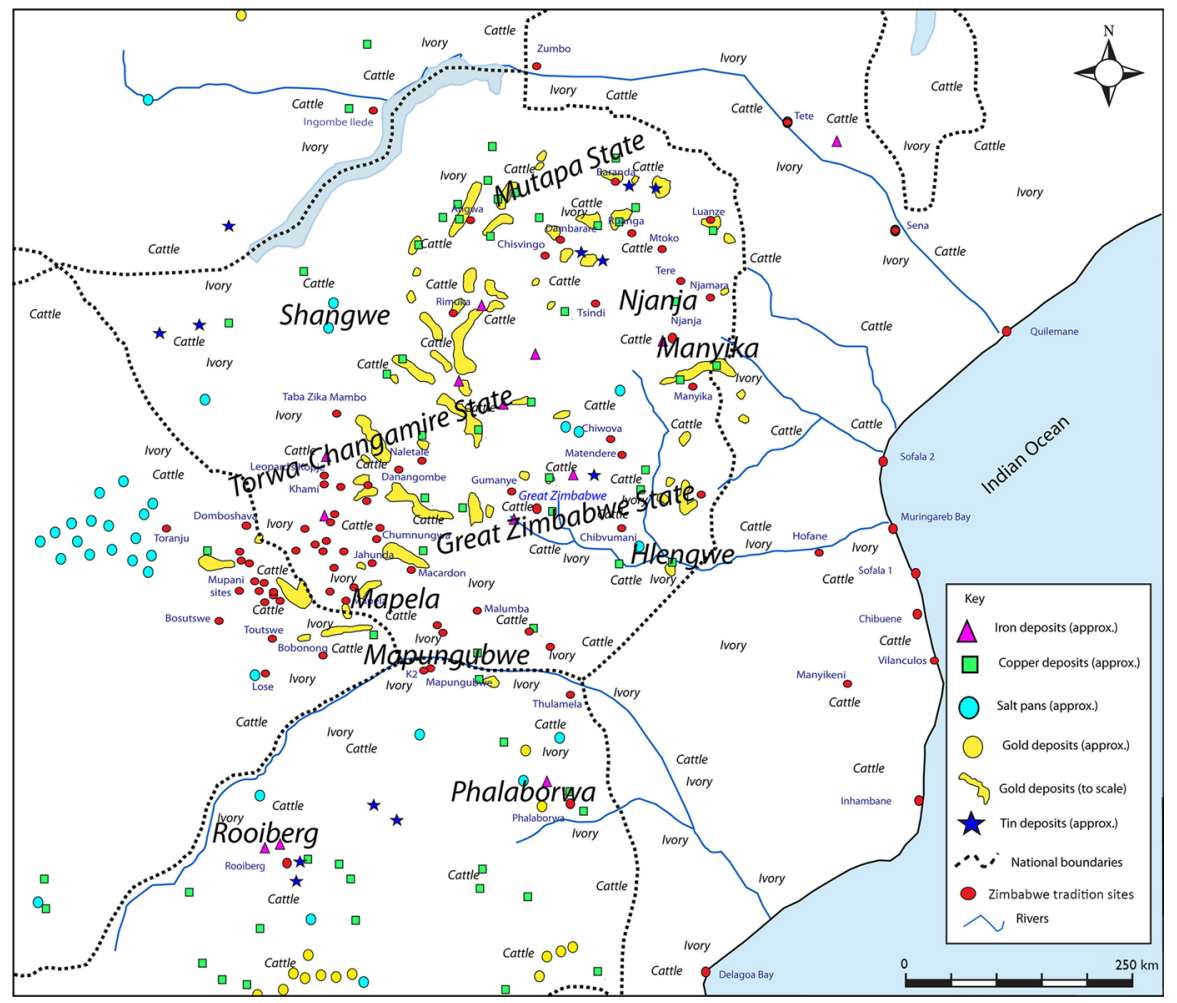

Fig. 5 The approximate distribution of sources of ore and other resources within the territory of the Great Zimbabwe state. 
copper, the nearest known mines are at Umkondo in Bikita, about $100 \mathrm{~km}$ to the southeast (Summers 1969). It is not clear where the cassiterite (tin ore) came from, but Caton-Thompson (1931) mentions sources in the hills near the site. Other possibilities include Cornucopia near Rusape, 300 km due east (Prendergast 1979). However, Great Zimbabwe also imported metals and alloys from other areas, such as tin from Rooiberg, $500 \mathrm{~km}$ away in northern South Africa (Grant 1999; Molofsky et al. 2014), and brass from the Indian Ocean rim (Bandama et al. 2017).

The current boundary of Great Zimbabwe was arbitrarily defined on the basis of colonial logics motivated by an "obsession with gold" and acquisition of land for settler agriculture. It had nothing to do with the concept of Great Zimbabwe as a cultural landscape whose full extent far exceeded the colonially demarcated boundaries. A survey for evidence of primary metal production and use within a 50-km radius of Great Zimbabwe (Mtetwa 2017) identified numerous iron smelting and smithing sites at Chigaramboni and Mashava. But no large mounds of slag, furnace remains, or related production debris were recovered neither at any of the sites on the broader landscape, nor at Great Zimbabwe itself (Chirikure 2007). The relatively small-scale nature of metal production at Great Zimbabwe is matched by the limited nature of metal fabrication on the wider cultural landscape (Bandama et al. 2016, 2017; Chirikure 2007, 2015; Mtetwa 2017).

\section{Pottery Production}

The abundance of domestic pottery (Fig. 6) from all occupation periods suggests that its production was a major craft activity at the site. Containers were made for cooking, for storage, and for serving food in mundane, ritual, and other contexts (Ndoro 1996). Typologically and spatially, the distribution of various pottery classes at Great Zimbabwe was restricted: Period I ceramics were recovered only from the Hill Complex and under the Maund Ruins by Caton-Thompson (1931; Robinson 1961a). Period II pottery was recovered only from the Hill Complex, whereas Period III ceramics came only from the Hill Complex and Great Enclosure areas. Period IV (Class 4) (Fig. 6) pottery had a universal distribution across all the areas, including walled and unwalled areas. Period V pottery (Class 5), however, is only known from a few samples (Robinson 1961a); based on recent excavations, most areas believed to represent this occupation layer are dominated by Class 4 pottery (Chirikure et al. 2018). Other areas labeled Period V by Sinclair et al. (1993), such as on the northern side of Mujejeje east of the site, are the remains of pole and dhaka houses of previous employees at the site built before the 1960s (Daniel Mugabe, personal communication 2016). Some of the houses are visible in historical photographs archived at the Great Zimbabwe Conservation Center.

What is remarkable about Great Zimbabwe's pottery, particularly from Periods II, III, and IV, is the high degree of standardization and uniformity in terms of shapes, sizes, and finish, particularly in vessels used for similar purposes (Fig 6). For example, while Period IV vessels were lavishly graphite burnished, they also were rarely decorated (Robinson 1961a). On this basis, Period IV pottery from walled areas is stylistically and functionally indistinguishable from that from unwalled settlements. This suggests high degrees of standardization, imitation, or continuity of local 


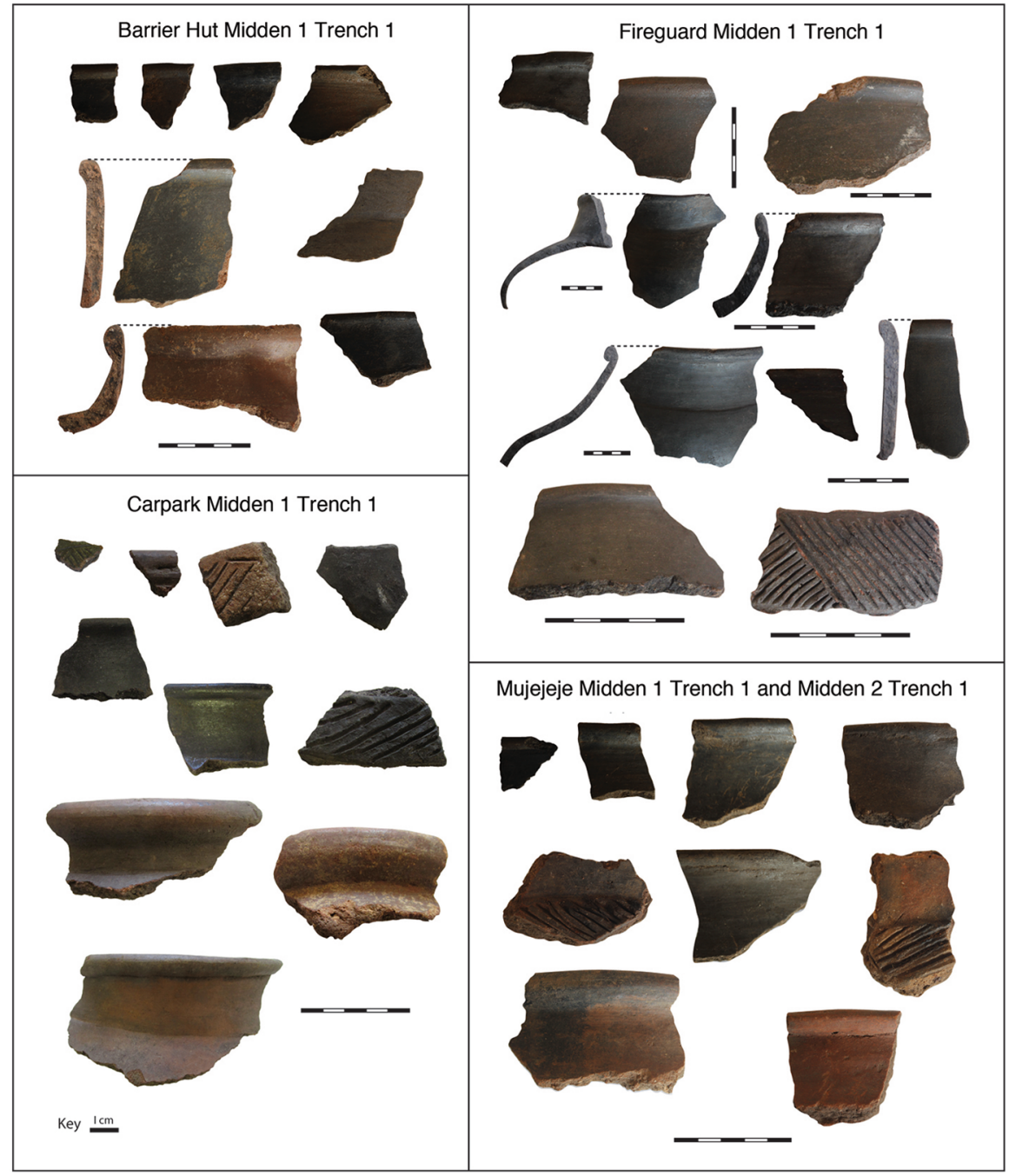

Fig. 6 Period IV pottery from selected unwalled settlements of Great Zimbabwe. Typical Period IV pottery comprises tall-necked pots, short-necked pots with everted rims, and pots with short necks and heavily rolled rims. The pots are lavishly decorated with graphite burnishing, although decoration is very rare.

potting practices. Mineralogical studies of pottery clay reveal that the clay used to make pots was granite derived and, as such, was likely local. However, no pottery production sites or kilns have been found within or around the site. Pottery from Ruanga, Zvongombe, and Kasekete in northern Zimbabwe, Gombe and Muchuchu in south-central Zimbabwe, Hlamba Mlonga to the southeast, and many other sites that chronologically overlap with Great Zimbabwe is stylistically similar, suggesting possible cultural and ideological connections over a very wide area (Caton-Thompson 1931; Garlake 1973; Pwiti 1996). 


\section{Weaving and Soapstone Carving}

Weaving was one of the major craft production activities practiced at Great Zimbabwe. The evidence for weaving is, however, mostly indirect, based on the recovery of ceramic discs (spindle whorls) used by 19th-century populations in northern Zimbabwe as fly wheels in the spinning of cotton on indigenous looms (CatonThompson 1931; Summers et al. 1961). Spindle whorls also were recovered from the various areas that make up the site. However, because of its perishable nature, no evidence of cloth is known from the site.

Great Zimbabwe yielded a wide assortment of soapstone objects, evidently worked on the site as indicated by flakes recovered from the Hill Complex. The most prominent objects include massive soapstone bowls, some of which were decorated with crops and animals, chevron patterns, and motifs (Chirikure and Pikirayi 2008). Other objects include small pendants and large, decorated soapstone columns. The most well-known objects from Great Zimbabwe are undoubtedly the eight soapstone birds recovered from the Hill Complex (seven) and the Valley Ruins (one) (Matenga 2011). Soapstone objects are generally interpreted as status and religious symbols that played an important role in the religion of Great Zimbabwe (Beach 1973; Garlake 1973); they may have represented deceased kings (Matenga 2011). So far, soapstone objects are restricted to the chronologically earlier walled areas on the Hill Complex, in the Valley Ruins, and in the Great Enclosure; they are unknown in the comparatively later unwalled settlements. This may be a function of the lack of work that has been done in unwalled areas compared to walled ones. According to Matenga (2011), the soapstone was quarried from sources 10-30 km from Great Zimbabwe. Soapstone also was worked at other Zimbabwe tradition sites, such as Danamombe on the Midlands and Chiumnungwa in Mberengwa, and so was not exclusive to Great Zimbabwe (Fig. 5).

\section{Drystone Walls}

Drystone walls (Fig. 7) are an easily recognizable and iconic category of material culture that expresses ideologies of status and prestige (Garlake 1973; Ndoro 2001)

Fig. 7 The interior of the eastern side of the Great Enclosure at Great Zimbabwe. The outer curtain wall is approximately 11 $\mathrm{m}$ high and $2 \mathrm{~m}$ wide. The drystone walls were a local status symbol representing "prestige," inequality, and hierarchy.

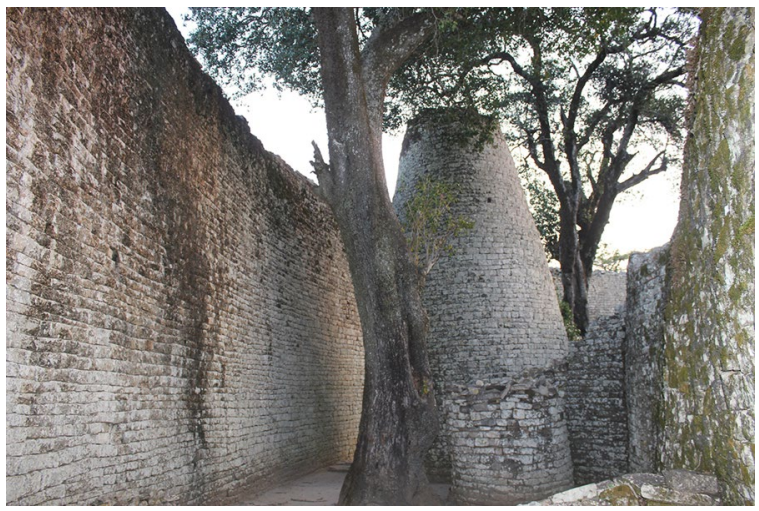


at Great Zimbabwe and related settlements. At Great Zimbabwe, it is estimated that millions of neatly cut and dressed granite blocks were used to build structures such as the outer curtain wall of the Great Enclosure (Garlake 1973). Quarries for the granite blocks are present in areas around the site. Based on the size of the walls, a significant amount of labor, skill, and time was invested in their construction. Within and outside the walls, houses of dhaka were built. Great Zimbabwe is littered with pits where the dhaka was extracted. Rough estimates are that thousands of tons of this raw material were consumed over time.

It is believed that the stone walls were constructed for ideological purposes as emblems of the rulers and as sources of local prestige (Pikirayi 2001). Despite limitations in research coverage, hundreds of drystone-walled sites are present all over the Zimbabwe plateau and in contiguous regions, suggesting that they represent a very important component of Shona life before the 19th century. However, the conclusions of research conducted to date do not facilitate the establishment of relationships between Great Zimbabwe and similar sites (Fig. 5). It is possible that there were many Zimbabwe-tradition states whose capitals were at places such as Danamombe, Thulamela, and many others.

\section{Animal Husbandry, Agriculture, and Hunting}

Based on the recovery of remains of domestic animals and crops, animal husbandry and crop agriculture were essential pillars of subsistence and economic production at Great Zimbabwe. The walled and unwalled areas of the site yielded a significant amount of faunal remains of both domestic and wild animals. Of the domesticates, cattle, goats, and sheep were abundant. Cattle bone recovered from the Hill Complex was dominated by young animals with unfused epiphyses (Thorp 1995). Excavations I led between 2014 and 2017 on the flats around the Carpark Midden, the Fireguard Midden, and Mujejeje uncovered cattle bone with a similar distribution skewed in favor of young animals. Across the site, the distribution of body parts was mixed, with no one area or assemblage dominated by specific body parts. The abundance of cattle bone shows that their raising was an important productive pursuit (Garlake 1973). Remnants of infrastructure for cattle keeping such as kraals are observed on the site.

Crop agriculture also formed an important component of the subsistence and economic base of Great Zimbabwe (Beach 1974). Excavations by Robinson (1961b) yielded charred remains of sorghum, one of the crops that alongside pearl and finger millets was a source of carbohydrate. Great Zimbabwe also has infrastructure for grain storage and processing such as granaries and grinding stones in various parts of the site. The plant economy and agricultural management systems at Great Zimbabwe, however, have not yet attracted detailed scientific research. No flotation was performed during most excavations at the site, resulting in a loss of information. Consequently, pending empirical research at the site, focus must be directed to crop agricultural practices evident in later periods to develop ideas that can be assessed through further fieldwork.

Hunting was a strong component of Great Zimbabwe's productive base. This activity yielded meat from wild animals as well as ivory and skins that were used for 
a variety of purposes including trade and exchange (De Luna 2016; Manyanga 2006; Manyanga and Pangeti 2017). Hunting demanded various forms of labor organization and mobilization. A traditional province for men, hunting could be performed individually, but often communities hunted together by trapping animals using nets (Beach 1974). A source of prestige, hunting was open to men of all ages and class to the extent that kings and chiefs also hunted, particularly for subsistence purposes (Chakaipa 1976).

\section{Circulation and Consumption of Commodities}

Evidence of consumption at Great Zimbabwe primarily appears in the remnants of organic and inorganic commodities that are associated with households dating to different time periods across the site. These include broken pottery, faunal remains, burnt sorghum seeds, metal production debris, and finished metal objects recovered at Great Zimbabwe itself and farther afield (Chirikure et al. 2018; Garlake 1973; Robinson 1961a). The mix of goods from local and nonlocal resources was procured through nested circulation networks that distributed inputs and finished products between individuals, households, communities, and perhaps even states (see Fig. 5).

Three profound issues affect any study of consumption and circulation at Great Zimbabwe. The first is that late $19^{\text {th }}$-century treasure hunters stripped virtually all deposits from key areas of the site such as the Great Enclosure. Objects were dispersed across the world's private collections and public holdings, some with records, others without. Secondly, unwalled settlements were traditionally considered unimportant in the single-minded focus on drystone-walled monuments. A combination of these factors makes it impossible to estimate the density of consumption from the frequency of objects recovered from various areas, based in turn on the ratio of artifacts to cubic meters of excavated deposit. Thirdly, comparatively little work has been conducted in the broader territory of the Great Zimbabwe state (Kusimba et al. 2017). Within the constraints imposed by the available evidence, it is still possible to throw some light on consumption trends and the circulation of commodities at Great Zimbabwe and beyond.

The drystone walls of Great Zimbabwe are not the only ones of their kind in the region: conservatively, there are more than 1000 similar sites scattered on the plateau and adjacent lowlands. While chronological relationships between these sites are not resolved, the presence of drystone walling over huge swathes of land attests to the circulation of ideas about power, prestige, ideology, values, and cultural practices within and between related peoples. Since each drystone-walled site is adapted to local topographic and other considerations, a great deal of local customizing is firmly stamped on the locations and designs of some of the walls.

Commodities such as grain, cattle, cloth, game meat, animal skins, and other organics were widely exchanged in precolonial southern Zambezia (Beach 1974). No doubt these were also consumed at Great Zimbabwe and circulated within the state. However, the limitations imposed by poor preservation make it difficult to reconstruct the circulation of organic materials at Great Zimbabwe and beyond. Consequently, not much can be said about their consumption other than that cattle 
were consumed in numbers (Garlake 1978). The high frequency of cattle bone at Great Zimbabwe indicates that hunted animals were not as prominent a source of meat as cattle were. However, this does not imply that the contribution of hunting to the diet at Great Zimbabwe was small. Often, carcasses of hunted animals were processed to debone the meat and dry it during hunting expeditions in the forest. The meat that was brought home had few bones, most of which were nondiagnostic (Manyanga and Pangeti 2017). Consequently, that bones of cattle are more abundant than those of wild animals is not a credible indicator of the actual contribution of hunting to the diet of farming communities in southern Africa (De Luna 2016). It simply reflects the affects of taphonomic factors; the organization of hunting and accumulation of refuse produced less visible signatures in the homesteads than cattle production and agriculture. Advances in scientific techniques may make it possible to reconstruct the circulation of cattle, but until then we have to contend with a paucity of evidence and rely on possible leads from the recent past.

Consumed for mundane, ritual, and other ends, domestic pottery is one of the most ubiquitous cultural materials recovered at Great Zimbabwe. The pottery is highly standardized in shape, surface finish, and decoration. Standardization relates to the circulation of ideas, techniques, and so on among producers and consumers; it also obscures the distribution of finished products. Fortunately, techniques from earth and engineering sciences permit studies of the provenance of archaeological pottery. Based on the principle that clays have a genetic relationship to the parent geology, pottery produced in areas with different geologies and lithologies can be easily separated. A limited number of samples of domestic pottery and crucibles from Great Zimbabwe were studied using a combination of thin-section petrography, scanning electron microscopy (SEM-EDS), and bulk X-ray fluorescence to characterize the fabric of the clays (Bandama et al. 2017). The work revealed that the clays used to make this suite of materials were granitic in source and thus local in origin. The only caveat is that there is a huge area in southern Zimbabwe that is dominated by granites of similar age and mineralogy. While indications are strong that the pottery was locally made, circulation through trade and other social transactions such as marriage negotiations and gifts over large distances cannot be ruled out. Further geochemical studies of pottery from various areas may illuminate wider networks and social interactions that pivot on ceramic production and use.

Ores and finished metal circulated at short and long distances at Great Zimbabwe and within the state. While Great Zimbabwe was a producer of metal, it also received processed metal and finished objects. Although goods could be locally produced, communities still accepted similar ones produced elsewhere, thereby "taking coals to Newcastle" and indicating interdependence in exchange systems. This is possible because other than necessities, social obligations and gifts are principal factors that drive the circulation of commodities in societies. For example, while local tin sources are present around Great Zimbabwe, neutron activation analysis (NAA) and lead isotope analyses of tin ingots reveal that Great Zimbabwe obtained metallic tin from Rooiberg, $500 \mathrm{~km}$ to the south in modern-day northern South Africa (Grant 1999; Molofsky et al. 2014). It is also possible that one of the leaded ingots had a different source altogether. This confirms that Great Zimbabwe participated in both near and wider networks of resource acquisition and circulation. 
The iron gongs recovered from the Hill Complex and the Valley Enclosures highlight the long-distance nature of Great Zimbabwe's commodities circuit. Ethnographically, iron gongs are not known in regions south of the Zambezi (Vansina 1969). Rather, their current distribution stretches from regions north of the Zambezi all the way to the Ivory Coast in West Africa. The gongs are not the only commodity used to establish a central African connection with Great Zimbabwe: archaeologists also found X-shaped copper ingots at Great Zimbabwe and other places that stylistically resemble those produced in the Copperbelt region of central Africa (Garlake 1973; Swan 2007). It is also possible that Great Zimbabwe recycled metal from various sources, particularly nonferrous metals and alloys, including copper and bronze. This practice would typically distort chemical and isotopic signatures so we should not assume that all metal was as pure as it was when acquired from furnaces.

Gold was an essential commodity that was worked and circulated at Great Zimbabwe and beyond. Based on the geological concentration of exploitable amounts of gold and the existence of "ancient workings," researchers have suggested that Great Zimbabwe's gold originated from various areas, some near, some far (Summers 1969). Very coarse chemical analyses of some gold from Great Zimbabwe showed that it contains very high levels of silver, between 12 and 2 wt.\%, the balance being gold. Geologically, the gold of the Zimbabwe plateau contains very high levels of silver. Until fine resolution work is performed, most ancient workings coeval with Great Zimbabwe are possible source candidates for the site's gold.

Beyond African commodities, Great Zimbabwe participated in broader networks of circulation that incorporated the Indian Ocean rim. Such circulation brought variable quantities of commodities from the Arabian Peninsula, the Indian subcontinent, Indonesia, and China to Great Zimbabwe and took commodities such as gold, ivory, and cloth from the state to these other world areas (Chirikure 2014). For example, there are variable amounts of glass beads dating from Periods II to V at Great Zimbabwe (Robertshaw et al. 2010; Robinson 1961b) (Fig. 8).

Fig. 8 Wound glass beads from Great Zimbabwe recovered from Period III contexts on the Hill. This high number is significant because other chronologically overlapping sites such as Mapungubwe have smaller numbers (Robertshaw et al. 2010).

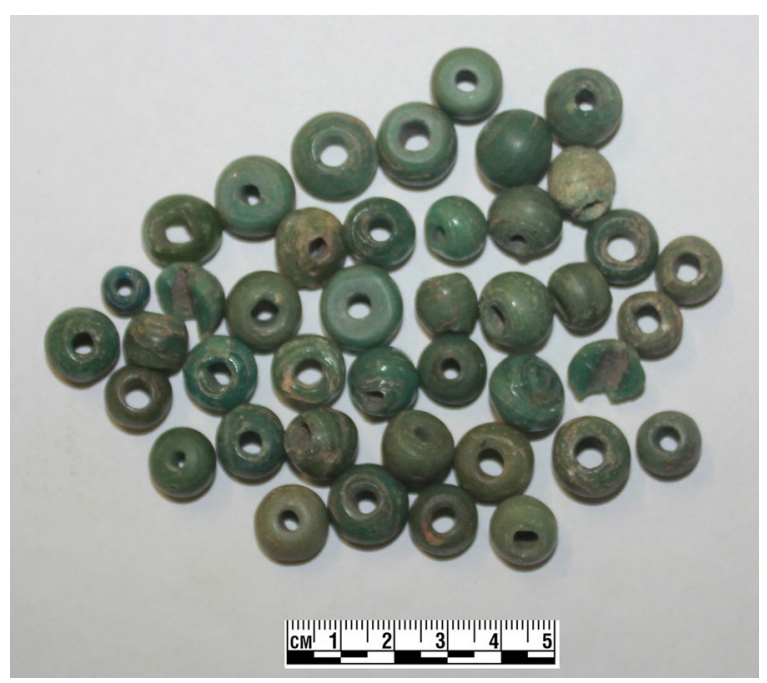


Fig. 9 Blue on white porcelain recovered from the Valley Enclosures and currently on display at the Great Zimbabwe site museum.

Fig. 10 Portuguese ceramic imitation of a conus shell (ndoro) recovered from Great Zimbabwe (Great Zimbabwe Conservation Center Archives File 2030BD) (source: S Chirikure).
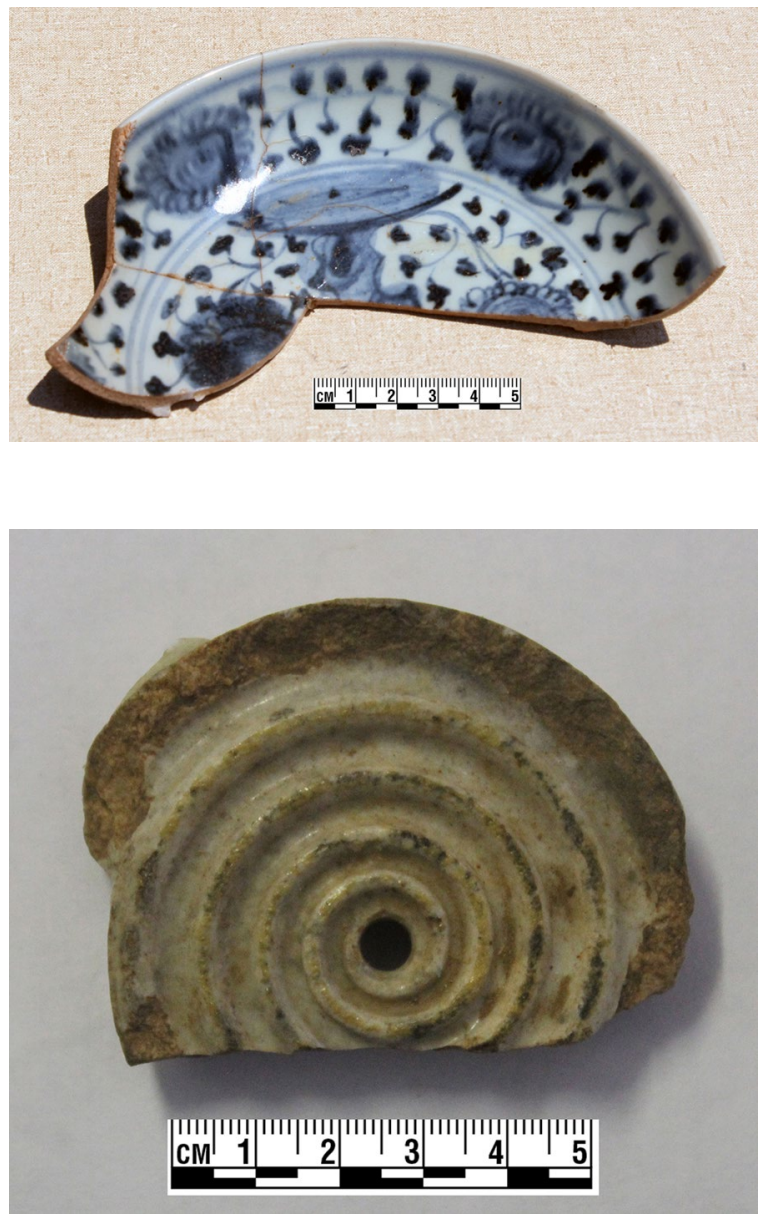

Other commodities from the Indian Ocean rim include Islamic and Chinese ceramics that ended up at Great Zimbabwe and related, chronologically overlapping sites (Fig. 9). The total number of imported ceramics at Great Zimbabwe is unlikely to exceed 100 (Collett et al. 1992; Garlake 1968), while that recovered from chronologically overlapping sites is even lower.

Archival investigations at the Great Zimbabwe Conservation Center found a ceramic disc made by the Portuguese in imitation of conus shells (ndoro). Typically, such shells were worn as pendants by Shona people, including chiefs (Ellert 1984). On recognizing the popularity of conus shells, the Portuguese manufactured facsimiles using clay (Fig. 10). The end product was glazed to create a white finish to mimic the natural conus. These Portuguese imitations are mostly known from northern Zimbabwe, in contexts that date from the 16th and 17th centuries onward (Ellert 1984). Thus, Great Zimbabwe was participating in the circulation of goods during the Portuguese period. This is material because Garlake's AD 1450 cutoff date for 
the flourishing of Great Zimbabwe made it appear that this social formation had collapsed by the time of the Portuguese in the early 16th century.

Of all the discoveries of objects ever made at Great Zimbabwe, an eclectic collection of local and nonlocal commodities from the Renders Ruin (Valley Enclosures) easily stands out, both for the spectacular find and for its implications for understanding circulation within the political economy. The highest concentration of glass beads is from the Renders Ruin hoard, more that 100,000. The hoard also includes a jade teapot, a Persian bowl bearing an inscription in Naskhi characters made in the 13 th or 14th century, fragments of Chinese celadon dishes, a piece of coral, a spoon, an iron lamp holder, a copper box, two copper finger rings, and two small bronze crotals (Garlake 1973, p. 132). What does this eclectic collection of local commodities and exotics symbolize? Does it represent conspicuous consumption by the elites, or was it a once-off gift by traders to facilitate permission to travel through and to trade? To answer these questions requires a detailed understanding of circulation, informed by comparison with insights from other sources, which I address below.

In summary, various lines of evidence of production, circulation, and consumption involving local commodities from short and long distances were recovered from different homesteads at Great Zimbabwe, alongside exotics in stratigraphic contexts corresponding to different occupation phases. What, however, are the implications of such evidence for exploring the political economy of Great Zimbabwe?

\section{Discussion: Crafting the Political Economy of Great Zimbabwe}

In this section, I consider the evidence of production and circulation at Great Zimbabwe, calibrated by local conditions and history, to add to the broader picture (Blanton and Fargher 2008; Chirikure 2014; DeMarrais and Earle 2017; Feinman and Nicholas 2012; McIntosh 1999; Stahl 2014). How were these socially embedded and interrelated elements (production and circulation) organized? Were they under centralized authorities, or were they devolved, with individuals, households, communities, and other social units expressing individual and collective enterprise? What ideologies underwrote production and circulation in the political economy? Here I highlight similarities and differences, with more recent ideas on production and circulation from global studies of political economy (e.g., DeMarrais and Earle 2017; Feinman 1998; Hirth 2009).

\section{Organization of Production in Historical and Ethnographic State and Nonstate Societies (AD 1500-1900)}

Great Zimbabwe had a vibrant economic system that, depending on the category of practice, was reliant on local inputs from nearby or at varying distances away from the capital, regional inputs from within Africa, and global inputs from beyond the continent. The paucity of well-resolved data at Great Zimbabwe itself, and the wider landscape, invites comparative insights with practices observed in the political 
economic successors of later periods. This is a step toward developing nuanced explorations of the organization of production in the broader archaeological picture.

Since Great Zimbabwe is acknowledged as a Shona political formation, it is essential to consider the organization of economic and production systems of states that existed between AD 1600 and 1900, notably the southwestern-based TorwaChangamire state (AD 1450-1900) and the northern-based Mutapa state (AD 1450-1900) (Fig. 11). These two territorial states were presided over by kings who ruled by divine right (Beach 1980; Mudenge 1988). Based on an ideology that linked ancestors, land control, and political power, Mutapa and Torwa-Changamire kings allocated land for cultivation to lower-level social units, such as households (Chirikure et al. 2017a; Mudenge 1988). Within state and nonstate societies, individual households (whether elite or commoner, high or low status) grew millets, sorghum, groundnuts, and cow peas using their own labor or that of servants and slaves (Mudenge 1988). Sometimes, all households, regardless of status, drew labor from other households in the community, through reciprocal, cooperative, and collective work parties. Work parties indebted households to other households by obligating them to provide labor and cooperate between households when the need arose. A form of collective action and source of social power (see DeMarrais and Earle 2017; Guyer 1996; Norman 2015; Stahl 2015), work parties also provided labor for construction, hunting, feasts, funerals, and much more (Gombe 1986). At the community level, political authorities (kings, chiefs, or local variations of these) had oversight over community fields that were worked using collective labor (Mudenge 1988). The output from such fields was used to feed households lacking sufficient food and for supporting community events and ceremonies (Bhila 1982; Gombe 1986; Mudenge 1988). Ideologically, such production was not about gaining profit or generating surplus: it was a step toward producing social power through reciprocal obligations to create relationships of dependency (e.g., Blanton and Fargher 2008). This social power became social capital that undergirded the concept of wealth-in-people intensively discussed in central African and West African political economies (c. AD 1500 -1900) (Guyer 2004; Norman 2015; Stahl 2015).

Raising cattle was universally recognized as a vital subsistence and economic practice that provided a source of food, wealth, and social power (Beach 1974;

Fig. 11 A Chinese jade teapot from the Renders Ruin, Great Zimbabwe; rather than being a luxury, this object may have been a gift offered to facilitate trade and other relations with Indian Ocean-based traders.

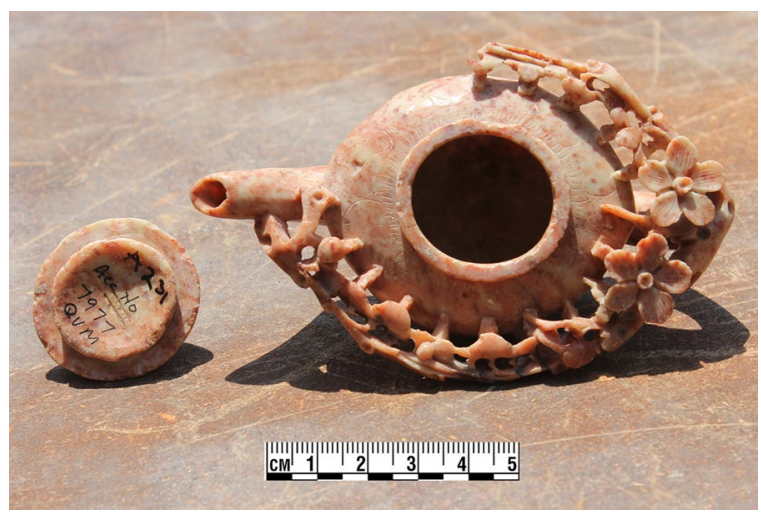


Denbow 1999; Mafeje 1991; Robertshaw 1999; Tsodzo 1976). In state and nonstate societies, herding was practiced during the agricultural months (September to April) to protect the crop fields (Gombe 1986; Scoones 1990). After the harvests, the cattle were let loose and often grazed the remains of crops in the fields. At night, cattle were penned to protect them from predators and thieves. Herding and penning as well as milking required labor, mostly that of men and boys (Gombe 1986). Individual households, kings, and chiefs all owned cattle, whose numbers gave them various levels of social status. Households living in the arid Mazvihwa area of southern Zimbabwe during the 19th and 20th centuries often practiced livestock transhumance to take advantage of the grazing potential of different ecological zones (Scoones 1990). However, this hardly exceeded distances of more than $30 \mathrm{~km}$.

An evaluation of the social and economic role of cattle shows that they were storable and reproducible wealth used to gain social, economic, and political clients, or to acquire wives through the payment of bride wealth (Beach 1974; Iliffe 1995; Kuper 1982; Tsodzo 1976). Cattle ownership, however, was not restricted to class: households at various levels of sociopolitical organization from the capital to villages could own them, quantities of which denoted wealth and status in society (Tsodzo 1976). Cattle provided meat and milk, while their hides were worked to produce items of clothing, mats, etc. Ideologically and spiritually, cattle were linked to ancestors (Tsodzo 1976). Households owned bulls that, after special ceremonies, became the host of the spirit of a deceased family leader. Subsequent to this personification, the bull protected both the herd and the living members of the family. Cattle, too, were a fundamental component of marriage negotiations, where they were used to symbolically compensate the bride's family for the loss of reproductive power to the groom's family. As a social process, bride wealth created social capital and relationships, which were easily converted into wealth-in-people. Politically, cattle played an important role in crystallizing diplomatic alliances between households, communities, and states (Mudenge 1974). According to Beach (1974, p. 11), among the 17th- and 20th-century Shona, when one had a kraal of cattle, whether inside a state or outside it, all had power; virtually all commodities from grain to salt, metallurgy, and exotics such as glass beads were eventually converted into wealth-in-cattle, which was a gateway to wealth-in-people (e.g., Guyer 2004). The mere possession of prestige goods such as cattle did not automatically give elites power; it was the conversion of ownership of cattle into social capital that created power.

For Shona mining and metallurgy, historical and ethnographic records from the 16th century and after show that these pursuits were seasonally specific and scheduled events that, within variation, exploited the labor of women, men, and children in both state and nonstate societies, (Beach 1974; Phimister 1974b). For example, Portuguese records on mining and metallurgy in the Mutapa and Torwa-Changamire states reveal that these categories of practice were winter activities (May to August/ September), performed after the agricultural cycle (Beach 1974; Mudenge 1988). During the craft production season, the organization of gold, copper, and iron mining was variable but drew on the individual and collective labor of men, women, and children (Mudenge 1988; Phimister 1974a). Among the chiefdoms, the 17thto-19th-century Njanja of central Zimbabwe extracted iron ore from the Hwedza 
Mountains through a combination of communal work parties and individual enterprise (Chirikure 2006; Mackenzie 1975). Elsewhere in Africa south of the Sahara, identical observations were made about copper mining in $19^{\text {th }}$-century Katanga, in the present-day Democratic Republic of the Congo (DRC) in central Africa (see Bisson 2000): mining took place as and when the need arose but generally outside the agricultural season.

Based on historical evidence, ownership and control of mines was not only variable but was often mixed in both state and nonstate societies. Shona chiefs in the area around the Angwa River in northern Zimbabwe had no direct control over gold washing between the 18th and 19th centuries (Phimister 1974b). According to Chanaiwa (1973), because of a land-control ideology underwritten by ancestral power, political authorities had custodial rights over the land and spirits of the land. This enabled them to collect a share of produce from all the mines, or a share of trade goods after the gold had been exchanged with the Portuguese. In the same area, outsiders were given permission to mine gold in different territories subject to the condition that they shared the output with the authorities (Phimister 1974b). The share of the kings was converted into resources such as cattle that were used to build a following.

In another example, the historically famous Njanja iron industry (c. AD 1700-1900) thrived on the mining of banded iron stone from the Hwedza Mountains (Fig. 5). The Njanja chiefs neither controlled these famous mines nor were they located in Njanja territory (Mackenzie 1975). And yet, the Njanja developed a very successful specialized and intensified iron production industry that supplied iron hoes within a 200-km radius (Chirikure 2006). Comparative evidence from Phalaborwa in South Africa shows that copper deposits at Lolwe, worked between AD 700 and 1900, were not under the control of kings in the 19th century (Moffett 2017; Thondhlana et al. 2016). The Rooiberg tin mines of northern South Africa, which were worked between AD 1300 and 1900, were similarly situated far from known state capitals (Bandama 2013). In Mali, West Africa, Dogon chiefs did not own mines (Huysecom and Augustoni 1997), neither did chiefs own the Bassari iron mines in Togo (De Barros 1988). Thus, access to mines was mostly open to all who could work them, but sometimes they were under the control of kings, chiefs, or local rulers. An ideology that gave ownership of land and other resources to the rulers also underwrote their ability to access a share of the production, which was not necessarily viewed as surplus (Chirikure 2007). The share was converted into cattle, grain, and other resources that were allocated to followers, thereby creating reciprocity and dependency typical of wealth-in-people options.

Archaeological studies in the territory of the historical Mutapa state in northern Zimbabwe and adjacent lowlands have identified dispersed metal production sites within homesteads at places such as Baranda, and outside them (Pikirayi 1993; Pwiti 1996). Similarly, an archaeological study of iron production by the Njanja located smelting sites near the iron mines at Gandamasungo and in Njanja villages about $50 \mathrm{~km}$ west of the mines (Chirikure 2006). Mutapa and Njanja iron production was practiced seasonally by independent specialists after the agricultural season. Njanja smelters attracted apprentices and followers, and therefore converted their coveted, specialist knowledge and skills into wealth-in-people (Mackenzie 1975). Some 
communities provided labor in return for iron, which built Njanja smelters a following to become chiefs. Despite this, Njanja iron production is referred to as specialized in the oral traditions, and no large-scale production mounds were located in any of the areas where they smelted iron (Chirikure 2006).

Another example is that provided by historical iron and copper smelting at Phalaborwa (AD 1500-1900) in South Africa. In this nonstate society, communities mined copper and iron, and smelted them around mines such as Lolwe Hill, or at homesteads such as Shankare and Putwana (Thondhlana 2013). The evidence for iron and copper smelting at Phalaborwa like that at Rooiberg is dispersed in variable concentrations on the landscape. The only exception at Phalaborwa is the site of Square, where an estimated 180 metric tons of slag formed huge mounds (Van der Merwe and Killick 1979, p. 91). While Square represents the largest known concentration of metal production debris in southern Africa, this is very small compared with the concentrated smelting in West African production regions such as Bassar in Togo that produced an estimated 80,000 metric tons of slag outside state-level organization between AD 1300 and 1700 (De Barros 1988). Similarly, iron production at Square and Phalaborwa was not under the control of a state (Moffett 2017; Van der Merwe and Scully 1971). These examples demonstrate that, in southern Africa, metal production was mostly dispersed on the landscape: in homesteads, away from them near the mines, and even far away from homesteads (see Chirikure 2015). Regardless of dispersion, such production was often large scale and produced output that intensively circulated locally and with the Indian Ocean rim (see Mackenzie 1975). The sum of output from dispersed systems achieved more or the less the same objectives as those of concentrated systems. Therefore, production systems that were variably organized (e.g., concentrated at Bassar, dispersed at Njanja) often produced similar outcomes-goods in excess of those required for household consumption. This explains why historical evidence makes it explicit that production by groups such as the Njanja, Phalaborwa, Bassar, and many others in sub-Saharan Africa was highly specialized but in culturally specific settings.

\section{Circulation of Commodities in Historical State and Nonstate Societies AD 1500- 1900}

What were the mechanics of circulation associated with dispersed systems of production characteristic of some political economies described above? The circulation of commodities within state (e.g., Mutapa and Torwa-Changamire) and nonstate societies (e.g., Njanja) took place at individual, interhousehold, and intercommunity levels, and wherever needs, wants, and supply and demand intersected (Chirikure 2014; Moffett and Chirikure 2016). An example of nonstate communities, salt producers in Marange in eastern Zimbabwe traded and exchanged salt for chicken, goats, cattle, grain, and other nonlocal resources, including imports such as cloth in the 19th century (Beach 1974). Sometimes, households visited salt production sites for exchange, while salt producers often travelled from household to household exchanging their produce. The Njanja adopted itinerancy as a strategy for circulation, traveling from village to village making iron and exchanging it for grain, cattle, 
chickens, and other resources, earning them the title of specialist iron producers and distributors. Circulation involved local and nonlocal commodities as well as necessities and exotics such as glass beads. It took place at transient markets that included homesteads, production centers, and periodic meeting places. However, although most of these historical groups were referred to as specialists, they remained fundamentally agricultural, so that the term "specialist" in the historical Shona economy does not imply total specialization (Beach 1974; Chirikure 2007). The gains from circulation were converted into social capital that enabled various leaders, specialists, producers, and distributors to build wealth-in-people (Beach 1974).

A critical assessment of commodities circulation in the Mutapa state offers insights into the organization of this sociocultural and politico-economic behavior within state-level society. Circulation took place at various scales, from the household through the community to interpolity levels, demonstrating the all-permeating and capillary nature of the political economy. According to Mudenge (1988), trade and exchange took place at mines, at homesteads, and at periodic but transient markets. Gold, iron, salt, and exotics such as cloth and glass beads could be exchanged, by anyone, anywhere, provided the season was optimal. The value of each transaction was variable depending on the expectations of those involved in the transaction. The prevailing ideology demanded that kings took a share of the proceeds from commodities circulation in whatever form. This "tax" or "rent" and not surplus could be traded or exchanged. Itinerancy was also an established circulation strategy in the Mutapa state. Intermediaries moved from village to village, and production site to production site, to trade and exchange. The Mutapa rulers did not monopolize circulation of local goods and exotics. Individuals could trade freely and often traveled to the coast in search of exotics, which they used to fulfill various social obligations. Exotics such as glass beads and cloth circulated as gifts between individuals, households, and communities and often were featured in marriage negotiations as gifts. The values of exotics did not remain static but changed depending on circumstances and how local people regarded them (Mudenge 1988).

Interesting dimensions to circulation within the Mutapa state emerged with the advent of the mercantilist-driven Portuguese during the 16th century (Phimister 1974b). The Portuguese built permanent trading settlements and markets such as Dambarare, Luanze, Zumbo, and Tete from where they traded (Chirikure 2014; Garlake 1969). These redistribution centers often had remnants of rectangular houses and significant quantities of exotics such as glass beads and Chinese porcelain. During the 18th and 19th centuries, the Portuguese based at Tete employed locals who traveled to the Angwa goldfields and other resource-rich areas in northern Zimbabwe with exotics such as cloth, glass beads, and guns. After exchanging exotics for gold, cloth, ivory, and iron with various households, the Portuguese emissaries returned to Tete with 20-30 lb of gold in a single season (Phimister 1974b). As part of the same circulation system, individual Africans traveled from the gold-washing areas to the Portuguese trading stations and to the Indian Ocean where they obtained cowries, glass beads, cloth, and other exotics (Mudenge 1988). State centers as well as elite and commoner homesteads that chronologically overlap with some of the markets, or feiras, have comparatively very small amounts of exotics (Chirikure 2014; Moffett and Chirikure 2016). Despite establishing permanent markets, 
the Portuguese did not monopolize trade, nor did their Mutapa principals control the multiscalar circulation networks that were in a constant state of flux. Unlike the Mutapa rulers-politics aside-the Portuguese lacked the ideological means to demand a share of production and proceeds from circulation, which prompted them to abandon some of the fixed markets.

Historians like Mudenge (1988) and Chanaiwa (1973) make explicit that circulation before the Portuguese was not based on permanent distribution and redistribution centers such as fixed markets. Traders and intermediaries followed rivers to and from the coast to various areas where people lived and worked (Bhila 1982). This model of mobile or transient circulation nodes was supported by an ideology that enabled rulers to obtain a share of commodities without controlling and monopolizing trade and exchange.

What was the value of exotics in the historical-period states and nonstate societies? Influenced by old models from regions such as Polynesia, the tendency was to assume that exotics in Africa were always luxuries that because of their rarity forever and always possessed prestige value. However, when incorporated in local value systems, exotics ceased to be exotics: they assumed local names, became local such that their value was interchangeable with that of similarly named local commodities. For example, glass beads were known as chuma while cowries were known as ndoro (Moffett and Chirikure 2016). The use of these exotics fit existing logics of spirituality, beauty, aesthetics, and personhood. Not surprisingly, exotics such as cloth, glass beads, cowries, and other local resources such as gold also were offered as gifts in marriage negotiations and were used in regalia by spirit mediums and healers (Moffett and Chirikure 2016). Still, gifts were gifts: in marriage negotiations, exotics rarely supplanted the symbolic and practical role of iron hoes and catthe that were offered to the bride's family as compensation for the loss of her reproductive power to another family. As such, nonproduction-related commodities (local commodities or exotics) were given only as gifts and became inalienable possessions (sensu Weiner 1985). In the event of divorce, hoes and cattle could be returned to the groom's family, but gifts such as glass beads, cloth, could not. Like value, the prestige of exotics was context specific and situational (Berry 2007). It was recently demonstrated that ownership of cattle and land, previously dismissed as a source of social power as well as possession of coveted knowledge, were more predictable sources of prestige and value than exotics (Chirikure 2014).

\section{Organization of Production and Circulation at Great Zimbabwe and Within the Zimbabwe State}

The picture emerging from historical and ethnographic observation, when assessed in relation to the archaeological evidence from Great Zimbabwe and beyond, offers some options for reflecting on the organization of production and commodities circulation at the site and beyond. To date, and in relative terms, no evidence of largescale production debris for crafts such as metallurgy, weaving, and even agricultural processing has been recovered at Great Zimbabwe or the wider area (Garlake 1973; Mtetwa 2017; Sinclair 1987). At Great Zimbabwe itself, that each settlement was 
associated with ferrous and nonferrous metallurgy, weaving, and other economic pursuits suggests the presence of multicrafting whereby households shifted labor and skills across activities. That each household was associated with evidence of craft production suggests that no one area of Great Zimbabwe itself and the wider state produced commodities such as metal for others, effectively ruling out any clearly defined product specialization and division of labor (Bandama et al. 2017; Chirikure 2007; Huffman 1972).

The prevalence of scatters of production debris at the site, around it, and near the chronologically overlapping production sites such as mines and salt pans indicates that dispersal and not concentration was the most common form of organization of production. However, the cumulative sum of relatively small scatters of production, when considered in space and time, aggregates into large-scale production (Chirikure 2015). Consequently, there appears to be convergence between historical and archaeological observations that relatively small-scale scatters of production at Great Zimbabwe itself and in the broader area attest to the existence of dispersed production systems for such crafts as metallurgy and possibly ivory working and salt production. Such production produced outcomes that fed into the Indian Ocean system. This is consonant with Arabic reports that mention the Zimbabwe plateau as a source of gold, ivory, iron, bark cloth, and other resources for the Indian Ocean. However, such systems may have been "specialized" within seasonal scheduling and produced results that circulated widely. Finally, it is possible that economic activities such as mining, salt production, hunting, and crafts like metal production during the time of Great Zimbabwe were variably organized, at homesteads in the capital, in the villages, and around the mines with the participation of men, women, and children, which demonstrates the capillary nature of production. It is possible that individuals may have traveled from Great Zimbabwe itself to the different sources of raw such as mines to extract gold, iron, and copper. Alternatively, Great Zimbabwe may through ideological sanction have accessed a share of output from the miners, metalworkers, and other producers. Whatever the mechanisms deployed at Great Zimbabwe, it is clear that gold, iron, copper, and perhaps tin from near and distant sources were brought to and taken away from the capital in multiple directions. This suggests the existence of vibrant internal networks for circulating resources between different areas in the state.

These craft activities may have been organized around crop agriculture and animal domestication. It is possible that fields belonging to the communities and households at Great Zimbabwe were nearby. Although remains of grain were recovered in the context of households at the site, some of the granaries at the site may have been centralized storage facilities. It is possible that individual homesteads situated outside the capital had their own storage facilities. Despite hosting a relatively high population, no infrastructure for irrigation or integrated water management has been recovered at Great Zimbabwe, either at the capital or in the broader state. This contrasts with the Nyanga agricultural system (AD 1300-1900) in eastern Zimbabwe, which has terraces and channels for water diversion into fields (Soper 2002). The inference is that rain-fed agriculture sustained farming at Great Zimbabwe. Harvesting plants from the bush and hunting were also an important component of the political economy (De Luna 2016; Manyanga 2006). 
The abundant cattle bone indicates that cattle raising was a key socioeconomic and political activity at Great Zimbabwe (Barker 1978; Garlake 1978; Thorp 1995). Individual households at the capital and in the broader state owned cattle herds. Garlake (1978) speculated that livestock transhumance based on alternating cattle between sourveld (coarse perennial grasses that afforded inferior grazing during the winter) and sweetveld (grasses that were nutritious during winter) was a fundamental cattle management tool at Great Zimbabwe. However, the transhumance hypothesis must be empirically tested with isotopic studies of cattle bone.

What ideology might have prevailed at Great Zimbabwe? The near-uniform patterning of production evidence at the site and on the broader landscape reveals that production was neither ad hoc nor restricted by social position. Elite and commoner households at the capital and in the broader territory participated in the same kinds of activities with nearly identical degrees of intensity and concentration. Although the nature of political organization was hierarchical, decision making and activities were more collective than coercive. This makes the heuristic labels "attached" or "independent" (sensu Costin 1991) somewhat redundant. Ideological control at Great Zimbabwe and within the wider state was expressed and reinforced by the presence of status symbols and ritual objects such as the soapstone birds, soapstone bowls, spearheads, iron gongs, and other objects. This ideology is further manifested by the presence of drystone-walled settlements of varying sizes within southern Africa. Drystone-walled sites such as Chiumnungwa, Danamombe, Thulamela, and Manyikeni have yielded gold, soapstone objects, iron gongs, and other objects that may have been status objects and symbols. Whether these sites were capitals of independent polities or not is another issue, but the combination of drystone walls and status symbols suggests the existence of ideological tools aimed at displaying and buttressing the power of rulers of individual states or related polities. This strategy of building monuments on the landscape has resonance with the Inka and Aztecs ideologies in South America (DeMarrais et al. 1996). The construction of drystone walls (Fig. 7) by communal work parties and other forms of labor shows the efficacy of cooperation and collective action in building prestige and status symbols (DeMarrais and Earle 2017). The elites would have reciprocated by providing land and other resources, thereby exerting their influence. It is possible that an ideology of building capitals of stone may have been tied to land control, which allowed rulers to "demand a share" of things. This wealth-in-things was likely converted into wealth-in-people, further concretizing relationships of dependency and reciprocity between the rulers and the ruled.

Closely tied to production, and guided by the same ideology, circulation was an essential element of the political economy of Great Zimbabwe. Great Zimbabwe yielded evidence of local and nonlocal commodities, some perishable, others not. The frequency of commodities recovered from various areas of Great Zimbabwe provides an indication of consumption trends through time and space. However, the history of looting at the site precludes a quantitative exploration of consumption based on the quantities of recovered local and imported objects. Notwithstanding this limitation, the picture that emerges is that local, regional, and imported commodities were all exploited at Great Zimbabwe. Yet more local commodities were consumed than regional and exotic ones. A rough calculation of the ratio of imported objects, 
such as glass beads, per cubic meter of deposit, yields a very low return for all areas of Great Zimbabwe (see also Garlake 1973; Robinson 1961b). This suggests that the circulation and consumption of exotics was not very high. Such an observation is similar to the picture from chronologically overlapping smaller drystone-walled sites that may have been part of the Zimbabwe state (Chirikure 2014). The only caveat is that cloth, one of the major imports from the Indian Ocean, is perishable and as such does not archaeologically preserve well. Overall, the low frequency of imports from outside the continent cautions against overestimating their quantities-characteristic of some literature on the topic. The presence of a single jade teapot, a single fragment of celadon, a few glass beads, etc., shows direct or indirect contact with the Indian Ocean, but whether it is evidence of symbolic and conspicuous consumption is debatable. While consumption at Great Zimbabwe itself was biased more in favor of local commodities and services that left less visible traces (e.g., cattle), debate on the role of exotics from the site must consider their multiple roles in society.

With the awareness that low numbers do not equate to low value, and that low numbers do not automatically translate into high value, it is essential to ask probing questions on the value and status of exotics from the Indian Ocean within the political economy of Great Zimbabwe. Were they rare, high status, and prestige symbols that were consumed only by elites as luxuries? As a counterbalance, is it appropriate to always assume that luxury and wealth are based only on the exotic? Furthermore, how does possession of a single Chinese jade teapot (Fig. 11) enable a king or queen to rule a territory of $50,000 \mathrm{~km}^{2}$ ? At issue here is the fact that the teapot is not as conspicuous as drystone walls and lacks the symbolic appeal of local icons such as soapstone birds. Examples from the historical period suggest that the status of imports - symbolic and otherwise-in the historical period was variable (Chirikure 2014; Moffett and Chirikure 2016). While the social status of exotic commodities such as glass beads was acknowledged as such, to the extent that individuals made trips to the coast, their value and significance was marginal and situational (Berry 2007; Guyer 2007). Distributed as gifts, possession of such exotics created socialstatus distinctions tied to notions and temporalities of personhood. Once obtained, they became inalienable possessions, which explains why most glass beads are from burials and not from other contexts such as middens. Therefore, social status was distinct from political status, which was underwritten by ancestry and birth (Mudenge 1988). More importantly, exotics never crossed a threshold where they could supplant the value of productive elements such as cattle, land, and iron hoes in the political economy.

The capillary nature of the political economy of Great Zimbabwe promoted equal access to imports for individuals and households across social strata, which explains why exotics have been found in elite and commoner households at Great Zimbabwe and beyond (Chirikure 2014). While the use of imports fit into local logics of ritual and aesthetics, their economic and political value was moderated by local context. As such, the low frequency of objects at Great Zimbabwe indicates that they were not used as symbols of political power. When available they may have been used in various contexts that augmented social status for commoners and elites alike. Even so, it is difficult to imagine glass beads, cowries, cloth, and porcelain being regarded as wealth. Ancestors, stone walls, and cattle would have provided far more stable 
pivots for wealth and symbolic power. In some African communities, it is common for objects associated with royal investiture to all be local in origin, with leaders who departed from this tradition often losing power (Mudenge 1988). Equally, it was known that the status of a person gave significance to objects and space. A mundane spear owned by a king had a higher status than a similar spear owned by a commoner, even if the two were forged by the same smith (Moffett and Chirikure 2016). Similarly, the status of a queen might have made the glass beads she owned more valuable than similar beads owned by a commoner. The complexity of value and significance as variables are situational and context dependent.

When compared to fixed Portuguese redistribution centers such as Dambarare, Great Zimbabwe yielded modest amounts of imports such as porcelain and glass beads (Chirikure 2014). This suggests that Great Zimbabwe was neither a fixed distribution nor a redistribution point. The variable manner in which goods, commodities, and services circulated ethnographically and historically indicates that circulation at Great Zimbabwe was likely based on a combination of exacting a share of production by the rulers and allowing individuals and households to freely trade among themselves. With such a mix of strategies, Great Zimbabwe's political economy was neither command-based nor fixed market-based (e.g., Feinman and Nicholas 2012). Instead, circulation took place at transient production and distribution centers where people worked and lived.

The presence of copper ingots that resemble those produced in Katanga in the DRC and iron gongs (Fig. 12) assumed to have originated from the same region are often used as evidence of the circulation of goods over $2000 \mathrm{~km}$ between Great Zimbabwe and central Africa (Swan 2007). While no scientific studies have been conducted for provenancing copper ingots and iron gongs, it is possible that their appearance was an outcome of a direct and indirect relay of ideas that stimulated imitation-inspired innovation at Great Zimbabwe and related places. What is of interest is that the iron gongs are from Danamombe, Chiumnungwa, Thulamela, and the coastal Zimbabwe-tradition site of Manyikeni. Were these objects luxuries, wealth, or exotics? Because they were made in the region, they appealed to identical logics of power and status that explain their use as status symbols. However, similarity in the absence of hard evidence does not say much. It is possible that the circulation of ideas and not physical objects resulted in the presence of identical objects across a wide area. For example, the Yoruba of Nigeria developed their own indigenous glass-making industry, which may have been stimulated by contact with

Fig. 12 A double-iron gong from Great Zimbabwe on display at the Natural History Museum in Bulawayo (source: $\mathrm{S}$ Chirikure).

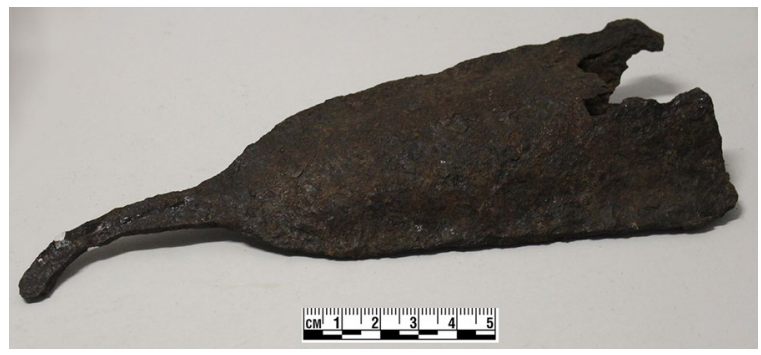


imported glass (Lankton et al. 2006). Generically, this confirms the idea that the political economy is not just about the movement of commodities but also the flow of ideas, people, and values. It is possible that some routes were more heavily used than others, while external exchange may have glommed onto local exchange routes. This makes the reconstruction of trade routes very important and challenging, given that circulation, like veins and arteries, branched into multiple directions that deeply connected the remotest and closest parts of the state and capital. However, with distance, such circulation networks morphed from local into regional, and from shortdistance into long-distance trade relationships that connected regions within Africa with the Indian Ocean world. In practice, this connectedness and glomming nature of exchange makes categories such as regional, local, and international circulation of little practical significance beyond analytical convenience (Chirikure 2017).

In sum, a consideration of the political economy of Great Zimbabwe at the interface of local, regional, and intercontinental interactions shows that insofar as exotics were incorporated into local contexts in innovative and inventive ways, there are thresholds that they did not cross in domains such as political power. Here, local ideologies based on ancestors and land were critical. The nature of that ideology also meant that inasmuch as wealth-in-things was converted into wealth-in-people, often where ancestors and land control intersected, they also were converted into wealthin-people. In cases where people built a power base founded on coveted knowledge, first comers to the land became ritual specialists for the second comers who then became political leaders (Kopytoff 1987). Often, there was some justification, religious or mythical, that accounted for the dominance of those who ascended to political power based on coveted knowledge (Chirikure 2006; Robertshaw 1999; De Maret 1999; Vansina 1999). One cannot, then, generalize that the concept of wealthin-people always applied in Africa, everywhere, because there were examples where variations existed.

\section{The Political Economy of Great Zimbabwe Within Local-Global Interfaces}

The most important issue confronting the social sciences is the extent to which human behavior is shaped by factors that operate cross-culturally as opposed to factors that are unique to particular cultures (Trigger 2003, p. 3)

An analysis of the political economy of Great Zimbabwe shows that most existing knowledge is based on extrapolating what is now older ideas of political economies from elsewhere. What is required, however, is a reconsideration of the local situation with new concepts and models from elsewhere to develop broad ideas about political economic formations (DeMarrais and Earle 2017; Feinman and Nicholas 2012; Hirth and Pillsbury 2013). As far as Great Zimbabwe is concerned, dispersion of production appears to be the commonly practiced way of organizing production. This is similar to prehispanic state formations in Mesoamerica (Feinman and Carballo 2018; Hirth and Pillsbury 2013) but significantly contrasts with known systems in regions such as Mesopotamia and Ancient Egypt where concentration 
was a hallmark of centralized and elite-controlled production systems. An ideology that emphasized social surplus in the form of wealth-in-people meant that material surpluses were not that important. Rather, the establishment of relationships of reciprocity that ensured a given social unit could call upon the collective labor of another was important (e.g., Blanton and Fargher 2009; DeMarrais and Earle 2017). Therefore, the idea of surplus representing only goods in excess of consumption requirements (Morehart and De Lucia 2015) does not always apply. Ideological contours conditioned whether communities valued material surpluses or social surpluses. That is not to say that Great Zimbabwe may not have produced material surpluses in areas such as cattle. The motivating logic would still be to build wealth in followers. A final point on production and its organization: although production was seasonally organized around subsistence as in prehispanic Mesoamerica, it is unlikely that concepts such as attached specialists or independent specialists are of great analytical aid in this context where social units were allowed individual and collective enterprise moderated by prevailing ideologies.

Great Zimbabwe's dispersed production system was also matched by a decentralized circulation system with no fixed distribution centers. While markets can be very difficult to document (Hirth and Pillsbury 2013), there is global variation, where some state systems had well-defined permanent markets that were absent in others. For Great Zimbabwe, this means that the influx of exotics from the Indian Ocean was not centrally monopolized or centrally redistributed. Such an arrangement raises important discussions about the role of exotics in the political economy of Great Zimbabwe. In some instances, local sources of prestige and status such as cattle, drystone walls, and land were more important politically than imports, whose role was mostly social. This explains why exotics exist in comparable frequencies in both commoner and elite settlements at Great Zimbabwe and chronologically overlapping sites (Moffett and Chirikure 2016). Social power, economic power, and political power, although related, are totally different things that should not be confused.

The locally centered approach that I adopt highlights interesting points of similarities and differences between Great Zimbabwe and political economies of states such as the Inka, Moche, Aztecs, and many others (Blanton and Fargher 2008; DeMarrais and Earle 2017; Feinman and Nicholas 2012). Although the principles are similar in that exotics (however defined) were present, the outward manifestation was very different. The capillary nature of the political economy of Great Zimbabwe required that individuals, households, and communities produced and circulated all forms of commodities, be they necessities, exotics, or luxuries, wherever and whenever demand and supply intersected. This was underpinned by an ideology that linked ancestors, land, and political power. While Great Zimbabwe was a territorial state with status symbols such as drystone-walled monuments and objects of power such as soapstone birds, iron gongs, and metal spearheads, its political economy was neither command-based nor market-based. This contradicts assumptions that economies of territorial states were always based on monopoly (e.g., Feinman 2016). In some contexts, ideology was more powerful in binding states and other social formations in a way that force and coercion could not achieve (DeMarrais et al. 1996).

Can the political economies of states function without centralized control? Undoubtedly (e.g., Feinman and Nicholas 2012; Hirth 2009), a political economy 
does not need central control or elite monopoly for it to operate (Feinman 2016). Guyer (2004) shows that production and circulation in Atlantic Africa from the 15th century onward also was hardly command based. Rather, the capillary nature of political economies makes it possible for production to circulate, encompassing all sectors of society. This contrasts with some models of hierarchical control that are often associated with polities in Mesopotamia and ancient Egypt (Stein 1998). This again shows variability in the organization of political economies among people that were spurred by different motives in different geographical zones at various time periods.

The dispersed nature of production and the lack of visibility for permanent distribution and storage centers raise significant questions about the concept of surplus as it is applied to global studies of ancient political economies (e.g., Morehart and De Lucia 2015). That circulation within a political economy may function without large production surpluses and yet produce commodities that end up on another continent is interesting. The historical evidence suggests that households or individuals only indulged in gold mining when they needed to acquire something through exchange of the gold and when the season was right (Mudenge 1988). Such an approach extremely frustrated the Portuguese who preferred all year-round gold production in northern Zimbabwe during the 16th and 17th centuries (Mudenge 1988). The Portuguese tried to set up fixed distribution centers in the interior, but because they possessed neither ideologically sanctioned powers nor military-enforced monopoly, they hardly changed anything. Great Zimbabwe would still appear to reach convergence with some systems in Africa where evidence of production and circulation shows that the volume of transactions was limited so that the gains from exchange transactions were marginal (see Guyer 2004). This may explain why no centralized storage facilities for grain or exotics have been recovered at Great Zimbabwe and related places, in contrast to territorial states with a different ideology such as the Hittites and the Inka (DeMarrais et al. 1996).

The low frequency of exotics at Great Zimbabwe raises important questions about their role, value, and significance in African communities and elsewhere. Traditionally, there was a tendency to assume that all exotics found in southern African were valuable because of their rarity (e.g., Pwiti 2005; also Ekholm 1978; Kipp and Schortman 1989). The narrative is that local production of gold and ivory, among others, was geared for external long-distance trade that brought in exotics such as glass beads. The distribution of glass beads then created surplus wealth that was converted by elites into political power. This undue emphasis on exotics as symbols of prestige and status was often accompanied by a tendency to exaggerate the value, quantities, and significance of exotics in African prehistory. For example, what does a single coin with Arabic inscription from Great Zimbabwe represent economically, symbolically, and politically? Can it be regarded as wealth, as a symbol of prestige? Similarly, what does the Renders Ruin 'hoard' from Great Zimbabwe mean in symbolic, wealth, and political economy terms? While these exotic finds indicate direct and indirect contact with the Indian Ocean, do these circumscribed finds represent luxuries and conspicuous consumption by the elites? This does not appear to be the case given the very specific context of recovery associated with goods that may have been destined for onward circulation (Garlake 1973). The hoard may have belonged 
to a trader who was passing through the capital, just as the coin may have been lost by a passing traveler. In some political economies such as ancient Egypt and the Inka, rulers controlled the production of crafts, exotics, and their distribution and redistribution, but this was not the case with Great Zimbabwe, whose operational logic was fundamentally different.

The unassessed assumption in southern Africa that all exotics were rare, highly valued luxuries - most of the time- - had the unfortunate consequence of closing off interesting debate on their other functions in the receiving societies. Consequently, the few exotics recovered from Great Zimbabwe may have been gifts offered to rulers to smooth trade and other interactions (Garlake 1973). Glass beads may have been fashion statements, changing with time, as the diachronic shifts in glass bead colors in southern Africa suggest (Robertshaw et al. 2010). It is equally plausible that glass beads were mundane objects that happened to have originated from a different region. As such, viewing exotics as rare and valuable prestige items all the time promotes a dangerous trope that wealth and luxury are only exotic and never local. And yet, it is well known that exotics were used within local logics where prestige and value were contextually defined (Stahl 2015). In the context of Great Zimbabwe, drystone walls and other local objects were inalienable status and prestige symbols whose political role was not supplantable by exotics. In other words, there are some thresholds that exotics could not cross. Historically, there are cases when states such as Mutapa nearly collapsed because rulers attempted to replace locally accepted symbols of status and prestige with exotics and alien ideologies such as Christianity (Mudenge 1988). Another dimension to this discussion is that exotics became local the moment they were incorporated into local contexts. To use a modern analogy_-with pardonable hyperbole_-most of the world wears clothing and uses products made in China, but rarely do people say: "I am wearing my Chinese-made suit" or "I enjoy using my Chinese-made iPhone" and so on. It is clear that more reflection is required on how exotics were internalized and how they may have gained or lost value as times changed. It is therefore inappropriate to view a single glass bead as representing prestige and wealth or a fragment of porcelain as luxury without considering interfaces, frictions, and thresholds those objects could and could not cross.

The situational nature of value in society poses important questions about concepts and categories such as exotic, local, luxury, long distance, and how they are used in the study of political economies globally. Generically, in Africa, exotics are mostly regarded as objects that originated outside the continent. Because of the distances from source areas to consumers, such exotics are viewed as luxuries whose use was restricted to the comfort of the elites. Meanwhile, local resources are often seen as mundane necessities less valuable than exotics. In this problematic narrative, long-distance trade is often associated with luxury, while short-distance is associated with necessities. Directly or indirectly, Great Zimbabwe exchanged ideas and commodities with central Africa, more than $2000 \mathrm{~km}$ away. This is in contrast with the Indian Ocean coast, which was only $300 \mathrm{~km}$ away and was the source of cowries. Although the coast is part of the African continent, it is traditionally associated with exotics to the extent that cowries from the Indian Ocean shores, when found in hinterland southern African sites such as Great Zimbabwe, are viewed as imported 
luxuries. Even more interesting is the view that objects from $2000 \mathrm{~km}$ away, such as the X-shaped Katanga copper ingots recovered at Great Zimbabwe, are considered neither global nor luxuries. And yet luxuries and prestige objects used by the Inka and Moche were recovered from the same continent. The definitional complexities embedded in these examples highlight the problem caused by looking at African communities from the outside, looking inside. Externally driven perspectives based on old theories promote the simplistic assumption that all objects from outside the African continent were prestigious luxuries enjoyed by the elites. Looking from inside facing out shows that exotics were transformed into local objects, were given local names, and were used in local contexts other than as luxury and prestige objects. In other words, the universe of use associated with exotics was unlimited but was situationally conditioned such that there were thresholds they could and could not cross.

\section{Closing Comments and Questions for the Future}

Although the political economy can be explored in many ways, privileging external concepts to study social formations such as Great Zimbabwe, as did the old approaches, was a necessary preliminary move, but as an end it was destined to be unsatisfactory. A study of Great Zimbabwe using locally centered concepts and comparison from broader studies of the political economy highlighted the presence of dispersed production and circulation systems that were household based. This is adequately supported by the absence of large accumulations of production debris and finished products relative to the populations at the time. Craft production and other economic activities were scheduled around subsistence activities, similar to some contexts in regions such as Mesoamerica. Collective action undergirded both production and circulation within a political economy that was decentralized.

Humans are always humans, which means that there are instances where their behavior is similar regardless of geography and time. However, those outward similarities often deceptively mask important context-mediated variations. Often, this has produced locally variable outcomes. Indeed, exotics featured in political economies of states and nonstate societies the world over, but the ways in which they were used were also different. Sometimes different approaches to local production and circulation produced similar outcomes, while at other times the converse holds true. Similarly, collective action and individual enterprise were key elements of political economies across the ages and the world. However, different and changing ideologies often meant that outcomes, too, were bound to differ. For example, the conversion of wealth-in-things into wealth-in-people, and variations of this, was an ideological strand that tied together many African political economies (Guyer and Belinga 1995). This often meant that emphasis was on producing social surplus and not on product surplus. The main point here is that collective action appeared in multiple shades globally to the extent that in parts of Africa cooperation was undergirded by an ideology that converted wealth-in-things into wealth-in-people. But similar strategies - collective action-led to similar and different outcomes in Africa and elsewhere, depending on the circumstances in which they were deployed. 
The concept of wealth-in-people is sometimes used as evidence that landownership was not of consequence in some African political economies (Guyer 1996). However, the land is a resource and a thing whose ownership was also converted into followers in historical states such as the Mutapa (Fig. 11). Even in cases where those with coveted knowledge and skills formed political formations, leadership gave them the right to distribute land. Chiefdoms and states are about territory, and territory is about land: without land there is no production. Therefore, multiple strategies such as ancestry, warfare, and/or use of coveted knowledge in crafts such as metalworking, hunting, rituals, were adopted to ensure control of the land and ultimately the people.

Going forward, a significant amount of effort must be invested in studying the political economy of sites and resource areas that are believed to have been part of the Great Zimbabwe state but are currently under-researched archaeologically. Such work will demand thorough surveys, detailed excavations supported by sound dating programs, and considered understanding of material culture drawing from Africancentered positions. When placed in a cross-cultural comparative envelope, in Africa and beyond, such work may further illuminate the peculiarities of local situations and sufficiently impress on global archaeology that selected African examples are worthy of serious consideration but are not representative of the entire continent. The fact that African examples sometimes contradict behaviors demonstrated elsewhere, outside the continent, should be viewed as interesting, even intriguing. Such examples attest to the diversity and inventiveness that characterize the development of the human species through space and time, across the world. This underscores the observation by Guyer (2007) that "Africa has never been traditional" to the extent that practices, values, places, and spaces were in a constant state of flux, influenced by interfaces between the internal and the external, the local and the global-essentially everything. The application of terms such as "glocal" in Africa and elsewhere downplays the importance of the local in configuring the global. And yet, the global is the net sum of various locals-here in Africa, and there outside the continentsuch that to explore the global, the starting point must be local.

Finally, because scales are interdependent, the political economy of Great Zimbabwe, like that of other African cities and states was based on an interaction of the local and the external (Chirikure 2014; Stahl 2014; Guyer and Belinga 1995; Kodesh 2010; McIntosh 1999; Norman 2015). It is only that old approaches tended to emphasize external factors at the exclusion of local ones (e.g., Chirikure et al. 2017d). Instead, studying Great Zimbabwe and other social formations using local concepts within a broader comparative perspective forces us to think of multiple options that enabled humanity in different parts of the world to deploy similar or different strategies, with operationally similar or operationally different results, across space and time. Such a frame of analysis, when conducted at a multiscalar level, brings much needed nuance to discussions of prehistoric political economies throughout the world, including Africa.

Acknowledgments Gary Feinman suggested the topic of political economy of Great Zimbabwe and offered incisive views, pivoted on a well-rounded understanding of political economies of premodern societies. Gary drew my attention to the quote by Bruce Trigger that opens the discussion section of this 
paper. I greatly appreciate his generosity and editorial guidance. The efforts and interventions of Linda Nicholas and the JARE editorial team are acknowledged with sincere gratitude. Discussions with Gilbert Pwiti, Chap Kusimba, Ann Stahl, Munyaradzi Manyanga, Bill Dewey, Allen Roberts, Pete Robertshaw, Foreman Bandama, David Schoenbrun, Susan McIntosh, Robert Nyamushosho, Catherine Damerell, and Simon Hall sharpened the thrust of this paper. Godfrey Mahachi and the National Museums and Monuments of Zimbabwe awarded permits for excavations at Great Zimbabwe. I am also indebted to the many colleagues who participated in my digs at Great Zimbabwe and beyond. I warmly acknowledge the very thorough comments from seven anonymous reviewers who suggested horizons that I initially had not dreamt of. Financial support from the University of Cape Town (Decoloniality grant) and the National Research Foundation of South Africa (Grants: 103 117, 105 861) supported this research. Errors and omissions that remain must, however, be solely attributed to me.

Open Access This article is distributed under the terms of the Creative Commons Attribution 4.0 International License (http://creativecommons.org/licenses/by/4.0/), which permits unrestricted use, distribution, and reproduction in any medium, provided you give appropriate credit to the original author(s) and the source, provide a link to the Creative Commons license, and indicate if changes were made.

\section{References Cited}

Bandama, F. (2013). The Archaeology and Technology of Metal Production in the Late Iron Age of the Southern Waterberg, Limpopo Province, South Africa, Ph.D. dissertation, Department of Archaeology, University of Cape Town, Cape Town.

Bandama, F., Moffett, A. J., Thondhlana, T. P., and Chirikure, S. (2016). The production, distribution and consumption of metals and alloys at Great Zimbabwe. Archaeometry 58: 164-181.

Bandama, F., Moffett, A. J., and Chirikure, S. (2017). Typological and technological attributes of metallurgical crucibles from Great Zimbabwe's (1000-1700 CE) legacy collections. Journal of Archaeological Science: Reports 12: 646-657.

Barber, K. (2007). When people cross thresholds. Special issue on Jane Guyer's Marginal Gains: Monetary Transactions in Atlantic Africa (2004). African Studies Review 50(2): 111+.

Barker, G. (1978). Economic models for the Manekweni Zimbabwe, Mozambique. Azania 13: 71-100.

Beach, D. N. (1973). Great Zimbabwe as a Mwari-cult centre. Rhodesian Prehistory 11: 11-13.

Beach, D. N. (1974). The Shona economy: Branches of production. Unpublished paper, Henderson Research Seminar Series, History Department, University of Rhodesia.

Beach, D. N. (1980). The Shona and Zimbabwe, 900-1850: An outline of Shona history, Mambo Press, Gwelo.

Beach, D. (1998). Cognitive archaeology and imaginary history at Great Zimbabwe 1. Current Anthropology 39: 47-72.

Beach, D., Bourdillon, M. F. C., Denbow, J., Hall, M., Lane, P., Pikirayi, I., Pwiti, G., and Huffman, T.N. (1997). Review feature: Snakes and crocodiles: Power and symbolism in ancient Zimbabwe, by Thomas Huffman. South African Archaeological Bulletin 52(166): 125-143.

Bent, J. T. (1896). The Ruined Cities of Mashonaland, Books of Rhodesia, Bulawayo.

Berry, S. (2007). Marginal Gains, market values, and history (Jane Guyer's 2004 Marginal Gains: Monetary Transactions in Atlantic Africa). African Studies Review 50(2): 57-70.

Bhila, H. H. K. (1982). Trade and Politics in a Shona Kingdom: The Manyika and Their African and Portuguese Neighbours, 1575-1902, Longman, Harlow.

Bisson, M. S. (2000). Precolonial copper metallurgy: Sociopolitical context. In Bisson, M. S., Childs, T. S., De Barros, P., Holl, A. F. C., and Vogel, J. C. Ancient African Metallurgy: The Socio-cultural Context, AltaMira Press, Walnut Creek, CA, pp. 83-146.

Blanton, R., and Fargher, L. (2008). Collective Action in the Formation of Pre-modern States, Springer, New York.

Blanton, R. E., and Fargher, L. F. (2009). Collective action in the evolution of pre-modern states. Social Evolution \& History 8: $133-166$.

Brumfiel, E. M., and Earle, T. K. (eds.), (1987). Specialization, Exchange, and Complex Societies, Cambridge University Press, Cambridge.

Caton-Thompson, G. (1931). The Zimbabwe Culture: Ruins and Reactions, Clarendon Press, Oxford. 
Chacon, R. J., and Mendoza, R. G. (eds.), (2017). Feast, Famine or Fighting? Multiple Pathways to Social Complexity, Springer, Cham, Switzerland.

Chanaiwa, D. (1973). The Zimbabwe Controversy: A Case of Colonial Historiography, East African Studies, No. 8, Syracuse University, Syracuse, NY.

Childe, V. G. (1950). The urban revolution. Town Planning Review 21(1): 3-17.

Chimhundu, H. (1992). Early missionaries and the ethnolinguistic factor during the 'invention of tribalism' in Zimbabwe. Journal of African History 33: 87-109.

Chirikure, S. (2006). New light on Njanja iron working: Towards a systematic encounter between ethnohistory and archaeometallurgy. South African Archaeological Bulletin 61: 142-151.

Chirikure, S. (2007). Metals in society: Iron production and its position in Iron Age communities of southern Africa. Journal of Social Archaeology 7: 72-100.

Chirikure, S. (2014). Land and sea links: 1500 years of connectivity between southern Africa and the Indian Ocean rim regions, AD 700-1700. African Archaeological Review 31: 705-724.

Chirikure, S. (2015). Metals in Past Societies: A Global Perspective on Indigenous African Metallurgy, Springer, Cham, Switzerland.

Chirikure, S. (2017). Documenting precolonial trade in Africa. Oxford Research Encyclopedia of African History, Retrieved 11 May 2018, from http://africanhistory.oxfordre.com/view/10.1093/ acrefore/9780190277734.001.0001/acrefore-9780190277734-e-68.

Chirikure, S. (2018). Early metallurgy and surplus without states in Africa south of the Sahara. Tagunden des Landesmuseums fur Vorgeschite Halle 18: 431-444.

Chirikure, S., and Pikirayi, I. (2008). Inside and outside the dry-stone walls: Revisiting the material culture of Great Zimbabwe. Antiquity 82: 976-993.

Chirikure, S., Mukwende, T., Moffett, A. J., Nyamushosho, R. T., Bandama, F., and House, M. (2017a). No big brother here: Heterarchy, Shona political succession and the relationship between Great Zimbabwe and Khami, southern Africa. Cambridge Archaeological Journal 28: 45-66.

Chirikure, S., Bandama, F., Chipunza, K., Mahachi, G., Matenga, E., Mupira, P., and Ndoro, W. (2017b). Seen but not told: Re-mapping Great Zimbabwe using archival data, satellite imagery and geographical information systems. Journal of Archaeological Method and Theory 24: 489-513.

Chirikure, S., Moultrie, T., Bandama, F., Dandara, C., and Manyanga, M. (2017c). What was the population of Great Zimbabwe (CE 1000-1800)? PloS ONE 12(6): e0178335.

Chirikure, S., Nyamushosho, R. T., Chimhundu, H., Dandara, C., Pamburai, H. H., and Manyanga, M. (2017d). Concept revision in the post-colony: Mukwerera rain imploring amongst the Shona of southern Africa. In Chirikure, S., and Manyanga, M. (eds.), Archives, Objects, Places and Landscapes: Multidisciplinary Approaches to Decolonised Zimbabwean Pasts, Langaa, Bamenda, p. 15.

Chirikure, S., Pollard, A. M., Manyanga, M., and Bandama, F. (2013). A Bayesian chronology for Great Zimbabwe: Re-threading the sequence of a vandalised monument. Antiquity 87: 854-872.

Chirikure, S., Manyanga, M., and Pollard, A. M. (2012). When science alone is not enough: Radiocarbon timescales, history, ethnography and elite settlements in southern Africa. Journal of Social Archaeology 12: 356-379.

Chirikure, S., Manyanga, M., Pollard, A. M., Bandama, F., Mahachi, G., and Pikirayi, I. (2014). Zimbabwe culture before Mapungubwe: New evidence from Mapela Hill, south-western Zimbabwe. PloS ONE 9(10): p.e111224.

Chirikure, S., Nyamushosho, R., and Bandama, F. (2018). Elites and commoners of Great Zimbabwe: Archaeological and ethnographic insights on social power. Antiquity 92: 1056-1075.

Cline, W. B. (1937). Mining and Metallurgy in Negro Africa, George Banta, Menasha.

Cobb, C. R. (1993). Archaeological approaches to the political economy of non-stratified societies. Archaeological Method and Theory 5: 43-100.

Cohen, R. (1965). Some aspects of institutionalized exchange: A Kanuri example. Cahiers d'Études Africaines 5(19): 353-369.

Collett, D., Vines, A., and Hughes, G. (1992). Dating and chronologies of the Valley Enclosures: Implications for the interpretation of Great Zimbabwe. African Archaeological Review 10: 139-161.

Costin, C. L. (1991). Specialization: Issues in defining, documenting, and explaining the organization of production. In Schiffer, M. (ed.), Archaeological Method and Theory, University of Arizona Press, Tucson, pp. 1-56.

Crumley, C. L. (1995). Heterarchy and the analysis of complex societies. In Ehrenreich, R. M., Crumley, C. L., and Levy, J. E. (eds.), Heterarchy and the Analysis of Complex Societies, Archeological Papers No. 6, American Anthropological Association, Arlington, VA, pp. 1-5. 
Dalton, G. (1977). Aboriginal economies in stateless societies. In Earle, T. K., and Ericson, J. T. (eds.), Exchange Systems in Prehistory, Academic Press, New York, pp. 191-212.

David, N., and Sterner, J. (1997). Water and iron: Phases in the history of Sukur. In Jungraithmayr, H. (ed.), L'homme et l'eau dans le basin du lac Tchad, Actes du Colloque Mega-Tchad, Colloques et Seminaires, Editions ORSTOM, Paris, pp. 255-270.

D'Altroy, T. N., and Earle, T. K. (1985). Staple finance, wealth finance, and storage in the Inka political economy. Current Anthropology 26: 187-206.

De Barros, P. (1988). Societal repercussions of the rise of large-scale traditional iron production: A West African example. African Archaeological Review 6: 91-113.

De Luna, K. M. (2016). Collecting Food, Cultivating People: Subsistence and Society in Central Africa, Yale University Press, New Haven, CT.

De Maret, P. (1999). The power of symbols and the symbols of power through time: Probing the Luba past. In McIntosh, S. K. (ed.), Beyond Chiefdoms: Pathways to Complexity in Africa, Cambridge University Press, Cambridge, pp. 151-165.

DeMarrais, E., Castillo, L. J., and Earle, T. (1996). Ideology, materialization, and power strategies. Current Anthropology 37: 15-31.

DeMarrais, E., and Earle, T. (2017). Collective action theory and the dynamics of complex societies. Annual Review of Anthropology 46: 183-201.

Denbow, J. (1999). Material culture and the dialectics of identity in the Kalahari: AD 700-1700. In McIntosh, S. K. (ed.), Beyond Chiefdoms: Pathways to complexity in Africa, Cambridge University Press, Cambridge, pp. 110-123.

Earle, T. K. (1987). Chiefdoms in archaeological and ethnohistorical perspective. Annual Review of Anthropology 16: 279-308.

Earle, T. K. (1997). How Chiefs Come to Power: The Political Economy in Prehistory, Stanford University Press, Stanford, CA.

Ehrenreich, R. M., Crumley, C. L., and Levy, J. E. (eds.) (1995). Heterarchy and the Analysis of Complex Societies, Archeological Papers No. 6, American Anthropological Association, Arlington, VA.

Ellert, H. (1984). The Material Culture of Zimbabwe, Longman, Harare.

Ekholm, K. (1978). External exchange and the transformation of central African social systems. In Friedman, J., and Rowlands, M. (eds.), Evolution of Social Systems, Duckworth, London, pp. 115-136.

Feinman, G. M. (2016). Reframing ancient economies: New models, old questions. In Fernandes-Götz, M., and Krausse, D. (eds.), Eurasia at the Dawn of History, Cambridge University Press, Cambridge, pp. 139-152.

Feinman, G. M., and Neitzel, J. (1984). Too many types: An overview of sedentary prestate societies in the Americas. Advances in Archaeological Method and Theory 7: 39-102.

Feinman, G. M. (1998). Scale and social organization: Perspectives on the archaic state. In Feinman, G. M., and Marcus, J. (eds.), Archaic States, School of American Research Press, Santa Fe, NM, pp. 95-133.

Feinman, G. M., and Nicholas, L. M. (2012). The late prehispanic economy of the Valley of Oaxaca, Mexico: Weaving threads from data, theory, and subsequent history. In Matejowsky, T., and Wood, D. C. (eds.), Political Economy, Neoliberalism, and the Prehistoric Economies of Latin America, Research in Economic Anthropology, vol. 32, Emerald, Bingley, UK, pp. 225-258.

Feinman, G. M., and Carballo, D. M. (2018). Collaborative and competitive strategies in the variability and resiliency of large-scale societies in Mesoamerica. Economic Anthropology 5: 7-19.

Fontein, J. (2006). The Silence of Great Zimbabwe: Contested Landscapes and the Power of Heritage, University College London Press, London.

Friedman, J., and Rowlands, M. (1977). Notes towards an epigenetic model for the evolution of 'civilization.' In Friedman, J., and Rowlands, M. (eds.), The Evolution of Social Systems, Duckworth, London, pp. 201-275.

Garlake, P. S. (1969). Excavations at the seventeenth-century Portuguese site of Dambarare, Rhodesia. Proceedings and Transactions of the Rhodesia Scientific Association 54: 23-61.

Garlake, P. S. (1968). The value of imported ceramics in the dating and interpretation of the Rhodesian Iron Age. Journal of African History 9: 13-33.

Garlake, P. S. (1973). Great Zimbabwe, Thames and Hudson, London.

Garlake, P. S. (1978). Pastoralism and Zimbabwe. Journal of African History 19: 479-493.

Gombe, J. M. (1986). Tsika dzava Shona (Our Values), Shona College Press, Harare.

Grant, M. R. (1999). The sourcing of southern African tin artefacts. Journal of Archaeological Science 26: $1111-1117$. 
Guyer, J. I. (1996). Traditions of invention in Equatorial Africa. African Studies Review 39(3): 1-28.

Guyer, J. I. (2004). Marginal Gains: Monetary Transactions in Atlantic Africa, University of Chicago Press, Chicago.

Guyer, J. I. (2007). Africa has never been "traditional": So can we make a general case? A response to the articles. African Studies Review 50(2): 183-202.

Guyer, J. I., and Belinga, S. M. E. (1995). Wealth in people as wealth in knowledge: Accumulation and composition in equatorial Africa. Journal of African History 36: 91-120.

Haas, J. (1982). The Evolution of the Prehistoric State, Columbia University Press, New York.

Haas, J. (2001). Warfare and the evolution of culture. In Feinman, G., and Price, T. D. (eds.), Archaeology at the Millennium, Springer, New York, pp. 329-350

Hall, M. (1990). "Hidden history" Iron Age archaeology in southern Africa. In Robertshaw, P. (ed.), A History of African Archaeology, James Currey, London, pp. 59-77.

Hall, R. N. (1905). Great Zimbabwe, Methuen, London.

Hirth, K. G. (1996). Political economy and archaeology: Perspectives on exchange and production. Journal of Archaeological Research 4: 203-239.

Hirth, K. G. (ed.) (2009). Housework: Craft Production and Domestic Economy in Ancient Mesoamerica, Archeological Papers No. 19, American Anthropological Association, Washington, DC.

Hirth, K. G., and Pillsbury, J. (eds.) (2013). Merchants, Markets, and Exchange in the Pre-Columbian World, Dumbarton Oaks, Washington, DC.

Huffman, T. N. (1972). The rise and fall of Zimbabwe. Journal of African History 13: 353-366.

Huffman, T. N. (1974). Ancient mining and Zimbabwe. Journal of the South African Institute of Mining and Metallurgy 74: 238-242.

Huffman, T. N. (1996). Snakes and Crocodiles: Power and Symbolism in Ancient Zimbabwe, Witwatersrand University Press, Johannesburg.

Huffman, T. N. (2007). Handbook to the Iron Age, University of KwaZulu-Natal Press, Scottsville.

Huffman, T. N., and Vogel, J. C. (1991). The chronology of Great Zimbabwe. South African Archaeological Bulletin 46: 61-70.

Huysecom, E., and Augustoni, B. (1997). Inagina: The Last House of Iron, PAVE Video, Geneva.

Iliffe, J. (1995). Africans: The History of a Continent, Cambridge University Press, Cambridge.

Kipp, R. S., and Schortman, E. M. (1989). The political impact of trade in chiefdoms. American Anthropologist 91: 370-385.

Klehm, C. E. (2017). Local dynamics and the emergence of social inequality in Iron Age Botswana. Current Anthropology 58: 604-633.

Kodesh, N. (2010). Beyond the Royal Gaze: Clanship and Public Healing in Buganda, University of Virginia Press, Charlottesville.

Kohl, P. L. (1989). The use and abuse of world-systems theory: The case of the "pristine" West Asian state. In Lamberg-Karlovsky, C. C. (ed.), Archaeological Thought in America, Cambridge University Press, Cambridge, MA, pp. 218-240.

Kopytoff, I. (1987). The African Frontier: The Reproduction of Traditional African Societies, Indiana University Press, Bloomington.

Kuper, A. (1982). Wives for Cattle: Bridewealth and Marriage in Southern Africa, Routledge and Kegan Paul, London.

Kusimba, C. M., Kim, N. C., and Kusimba, S. B. (2017). Trade and state formation in ancient east African coast and southern Zambezia. In Chacon, R. J., and Mendoza, R. G. (eds.), Feast, Famine or Fighting? Multiple Pathways to Social Complexity, Springer, Cham, Switzerland, pp. 61-89.

Lan, D. (1985). Guns and Rain: Guerrillas and Spirit Mediums in Zimbabwe, University of California Press, Los Angeles.

Lane, P. (1994). The use and abuse of ethnography in the study of the southern African Iron Age. Azania: Archaeological Research in Africa 29: 51-64.

Lane, P. (2005). Barbarous tribes and unrewarding gyrations? The changing role of ethnographic imagination in African archaeology. In Stahl, A. B. (ed.), African Archaeology: A Critical Introduction, Blackwell, Oxford, pp. 24-54.

Lankton, J. W., Ige, O. A., and Rehren, T. (2006). Early primary glass production in southern Nigeria. Journal of African Archaeology 4: 111-138.

Mackenzie, J. M. (1975). A pre-colonial industry: The Njanja and the iron trade. Nada 11: 200-220.

Mafeje, A. (1991). The Theory and Ethnography of African Social Formations: The Case of the Interlacustrine Kingdoms, CODESRIA, Dakar. 
Mahachi, G., and Ndoro, W. (1997). The socio-political context of southern African Iron Age studies with special reference to Great Zimbabwe. In Pwiti, G. (ed.), Caves, Monuments and Texts: Zimbabwean Archaeology Today, Department of Archaeology and Ancient History, Uppsala University, Uppsala, pp. 89-104.

Makoni, S. B. (2013). An integrationist perspective on colonial linguistics. Language Sciences 35: 87-96.

Manyanga, M., and Pangeti, G. (2017). Precolonial hunting in southern Africa: A changing paradigm. In Manyanga, M., and Chirikure, S. (eds.), Archives, Objects, Places and Landscapes: Multidisciplinary Approaches to Decolonised Zimbabwean Pasts, Langaa, Bamenda, pp. 277-285.

Manyanga, M. (2006). Resilient Landscapes: Socio-environmental Dynamics in the Shashi-Limpopo Basin, Southern Zimbabwe c. AD 800 to the Present, Ph.D. dissertation, Department of Archaeology and Ancient History, Uppsala University, Uppsala.

Matenga, E. (2011). The Soapstone Birds of Great Zimbabwe: Archaeological Heritage, Religion and Politics in Postcolonial Zimbabwe and the Return of Cultural Property, Ph.D. dissertation, Department of Archaeology and Ancient History, Uppsala University, Uppsala.

Mauch, K. (1874). Carl Mauch's Reisen im Inneren von Süd-Afrika: 1865-1872: Mit einer Originalkarte, J. Perthes, Gotha.

McIntosh, S. K. (ed.) (1999). Beyond Chiefdoms: Pathways to Complexity in Africa, Cambridge University Press, Cambridge.

McIver, D. R. (1906). Mediaeval Rhodesia, Macmillan, London.

Miller, D. (2002). Smelter and smith: Iron Age metal fabrication technology in southern Africa. Journal of Archaeological Science 29: 1083-1131.

Moffett, A. J. (2017).'Phalaborwa Where the Hammer is Heard': Crafting Together the Political Economy of Iron Age Communities in Southern Africa, AD 900-1900, Ph.D. dissertation, Department of Archaeology, University of Cape Town, Cape Town.

Moffett, A. J., and Chirikure, S. (2016). Exotica in context: Reconfiguring prestige, power and wealth in the southern African Iron Age. Journal of World Prehistory 29: 337-382.

Molofsky, L. J., Killick, D., Ducea, M. N., Macovei, M., Chesley, J. T., Ruiz, J., Thibodeau, A., and Popescu, G. C. (2014). A novel approach to lead isotope provenance studies of tin and bronze: Applications to South African, Botswanan and Romanian artifacts. Journal of Archaeological Science 50: $440-450$.

Monroe, J. C., and Ogundiran, A. (eds.) (2012). Power and Landscape in Atlantic West Africa: Archaeological Perspectives, Cambridge University Press, Cambridge.

Moore, D. S. (2005). Suffering for Territory: Race, Place, and Power in Zimbabwe, Duke University Press, Durham, NC.

Morehart, C. T., and De Lucia, K. (2015). Surplus: The politics of production and the strategies of everyday life: An introduction. In Morehart, C. T., and De Lucia, K. (eds.), Surplus: The Politics of Production and the Strategies of Everyday Life, University Press of Colorado, Boulder, pp. 3-44.

Morrison, K. D. (1994). The intensification of production: Archaeological approaches. Journal of Archaeological Method and Theory 1: 111-159.

Mtetwa, E. 2017. Technology, Ideology and Environment: The Social Dynamics of Iron Metallurgy in Great Zimbabwe, AD 900 to the Present, Ph.D. dissertation, Department of Archaeology and Ancient History, Uppsala University, Uppsala.

Mtetwa, R. M. (1976). The Political and Economic History of the Duma People of South-eastern Rhodesia from the Early Eighteenth Century to 1945, Ph.D. dissertation, University of Rhodesia, Salisbury.

Mudenge, S. I. (1974). The role of foreign trade in the Rozvi empire: A reappraisal. Journal of African History 15: 373-391.

Mudenge, S. I. (1988). A Political History of Munhumutapa c 1400-1902, James Currey, London.

Ndoro, W. (1996). Towards the meaning and symbolism of archaeological pottery assemblages. In Pwiti, G., and Soper, R. (eds.), Aspects of African Archaeology: Papers from the 10th Congress of the PanAfrican Association for Prehistory and Related Studies, University of Zimbabwe, Harare, pp. $773-780$.

Ndoro, W. (2001). Your Monument Our Shrine: The Preservation of Great Zimbabwe, Ph.D. dissertation, Department of Archaeology and Ancient History, Uppsala University, Uppsala.

Norman, L. (2015). Surplus houses: Palace politics in the Bight of Benin West Africa, AD 1650-1727. In Morehart, C. T., and De Lucia, K. (eds.), Surplus: The Politics of Production and the Strategies of Everyday Life, University Press of Colorado, Boulder, pp. 203-220. 
Pearson, H. W. (1957). The economy has no surplus: Critique of a theory of development. In Polanyi, K., Arensberg, C. M., and Pearson, H. W. (eds.), Trade and Market in the Early Empires: Economies in History and Theory, Free Press, Glencoe, IL, pp. 320-341.

Phimister, I. R. (1974a). Ancient mining near Great Zimbabwe. Journal of the South African Institute of Mining and Metallurgy 74: 233-237.

Phimister, I. R. (1974b). Alluvial gold mining and trade in nineteenth-century south central Africa. Journal of African History 15: 445-456.

Pikirayi, I. (1993). The Archaeological Identity of the Mutapa State, Studies in African Archaeology No. 6, Department of Archaeology, Uppsala University, Uppsala.

Pikirayi, I. (2001). The Zimbabwe Culture: Origins and Decline of Southern Zambezian States, AltaMira, Oxford.

Polanyi, K., Arensberg, C. M. P., Harry, W., Conrad, M. A., and Harry, W. P. (1957). Trade and Market in the Early Empires: Economies in History and Theory, Free Press, New York.

Prendergast, M. D. (1979). Cornucopia: Phase 1 Zimbabwe stone buildings associated with an Iron Age tin mine. Rhodesian Prehistory 17: 11-16.

Prestholdt, J. (2008). Domesticating the World: African Consumerism and the Genealogies of Globalization, University of California Press, Berkeley.

Pwiti, G. (1991). Trade and economies in southern Africa: The archaeological evidence. Zambezia 18: 119-129.

Pwiti, G. (1996). Continuity and Change: An Archaeological Study of Farming Communities in Northern Zimbabwe AD 500-1700, Studies in African Archaeology No. 13, Uppsala University, Uppsala.

Pwiti, G. (2005). Southern Africa and the east African coast. In Stahl, A. B. (ed.), African Archaeology: A Critical Introduction, Blackwell, Oxford, pp. 378-391.

Ranger, T. O. (1983). The invention of tradition in colonial Africa. In Hobsbawm, E., and Ranger, T. (eds.), The Invention of Tradition, Cambridge University Press, Cambridge, pp. 211-262.

Redmond, E. M. (ed.) (1998). Chiefdoms and Chieftaincy in the Americas, University Press of Florida, Gainesville.

Renfrew, C. (1975). Trade as action at a distance: Questions of integration and communication. Ancient Civilization and Trade 3: 3-59.

Rice, P. M. (1981). Evolution of specialized pottery production: A trial model [and comments and reply]. Current Anthropology 22: 219-240.

Robertshaw, P. (1999). Seeking and keeping power in Bunyoro-Kitara, Uganda. In McIntosh, S. K. (ed.), Beyond Chiefdoms: Pathways to Complexity in Africa, Cambridge University Press, Cambridge, pp. 124-135.

Robertshaw, P., Wood, M., Melchiorre, E., Popelka-Filcoff, R. S., and Glascock, M. D. (2010). Southern African glass beads: Chemistry, glass sources and patterns of trade. Journal of Archaeological Science 37: 1898-1912.

Robinson, K. (1961a). Zimbabwe pottery. Occasional Papers of the National Museums of Rhodesia 3(23A): 193-226.

Robinson, K. (1961b). Excavations on the Acropolis Hill. Occasional Papers of the National Museums of Rhodesia 3(23A): 159-192.

Roseberry, W. (1989). Anthropologies and Histories: Essays in Culture, History, and Political Economy, Rutgers University Press, New Brunswick, NJ.

Rowlands, M. (1989). A question of complexity. In Miller, D., Rowlands, M., and Tilley, C. (eds.), Domination and Resistance, Unwin Hyman, London, pp. 29-40.

Scoones, I. C. (1990). Livestock Populations and the Household Economy: A Case Study from Southern Zimbabwe, Ph.D. dissertation, Imperial College London, London.

Scott, J. C. (2009). The Art of Not Being Governed: An Anarchist History of Upland Southeast Asia, Yale University Press, New Haven, CT.

Service, E. (1975). Origins of the State and Civilization: The Process of Cultural Evolution, Norton, New York.

Shennan, S. (1993). Commodities, transactions, and growth in the central-European early Bronze Age. Journal of European Archaeology 1(2): 59-72.

Sinclair, P. J. (1987). Space, Time and Social Formation: A Territorial Approach to the Archaeology and Anthropology of Zimbabwe and Mozambique c. 0-1700 AD, Societa Archaeologica Uppsaliensis, Uppsala. 
Sinclair, P. J., and Petrén, M. (2010). Exploring the interface between modern and traditional information systems: The case of Great Zimbabwe. Unpublished manuscript, Sub-Department of African and Comparative Anthropology, Uppsala University, Uppsala, Sweden.

Sinclair, P. J., Pikirayi, I., Pwiti, G., and Soper, R. (1993). Urban trajectories on the Zimbabwean plateau. In Shaw, T., Sinclair, P., Andah, B., and Okpoko, A. (eds.), The Archaeology of Africa: Food, Metals and Towns, Routledge, London, pp. 705-731.

Smith, M. E. (2004). The archaeology of ancient state economies. Annual Review of Anthropology 33: 73-102.

Soper, R. C. (2002). Nyanga: Ancient Fields, Settlements and Agricultural History in Zimbabwe, British Institute in Eastern Africa, London.

Stahl, A.B. (1993). Concepts of time and approaches to analogical reasoning in historical perspective. American Antiquity 58: 235-260.

Stahl, A. B. (2004). Political economic mosaics: Archaeology of the last two millennia in tropical sub-Saharan Africa. Annual Review of Anthropology 33: 145-172.

Stahl, A. B. (2014). Africa in the world: (Re)centering African history through archaeology. Journal of Anthropological Research 70: 5-33.

Stahl, A. B. (2015). The transactional dynamics of surplus in landscapes of enslavement. In Morehart, C. T., and De Lucia, K. (eds.), Surplus: The Politics of Production and the Strategies of Everyday Life, University Press of Colorado, Boulder, pp. 267-306.

Stein, G. (1998). Heterogeneity, power, and political economy: Some current research issues in the archaeology of Old World complex societies. Journal of Archaeological Research 6: 1-44.

Summers, R. (1969). Ancient Mining in Rhodesia and Adjacent Areas, Museums Memoir No. 3, National Museums and Monuments of Rhodesia, Salisbury.

Summers, R., Robinson, K. R., and Whitty, A. (1961). Zimbabwe excavations, 1958. Occasional Papers of the National Museums and Monuments of Southern Rhodesia, Series A, Human Sciences 3: 226-333.

Swan, L. M. (2007). Economic and ideological roles of copper ingots in prehistoric Zimbabwe. Antiquity 81: 999-1012.

Thondhlana, T. P. (2013). Metalworkers and Smelting Precincts: Technological Reconstructions of Second Millennium Copper Production around Phalaborwa, Northern Lowveld of South Africa, Ph.D. dissertation, University College London, London.

Thondhlana, T. P., Martinón-Torres, M., and Chirikure, S. (2016). The archaeometallurgical reconstruction of early second-millennium AD metal production activities at Shankare Hill, northern Lowveld, South Africa. Azania: Archaeological Research in Africa 51: 327-361.

Thorp, C. R. (1995). Kings, Commoners and Cattle at Zimbabwe Tradition Sites, Museum Memoir (New Series) 1, National Museums and Monuments of Zimbabwe, Harare.

Trigger, B. G. (2003). Understanding Early Civilizations: A Comparative Study, Cambridge University Press, Cambridge.

Tsodzo, T. K. M. (1976). Cattle are our bank. In Kliff, C., and Kliff, P. (eds.), Shona Customs, Gombe Press, Harare.

Van der Merwe, N. J., and Killick, D. J. (1979). Square: An iron smelting site near Phalaborwa. South African Archaeological Society Goodwin Series 3: 86-93.

Van der Merwe, N. J., and Scully, R. T. (1971). The Phalaborwa story: Archaeological and enthnographic investigation of a South African iron age group. World Archaeology 3: 178-196.

Vansina, J. (1969). The bells of kings. Journal of African History 10: 187-197.

Vansina, J. (1989). Deep-down time: Political tradition in central Africa. History in Africa 16: 341-362.

Vansina, J. (1999). Pathways of political development in equatorial Africa and neo-evolutionary theory. In McIntosh, S. K. (ed.), Beyond Chiefdoms: Pathways to Complexity in Africa, Cambridge University Press, Cambridge, pp. 166-172.

Wallerstein, I. (1974). The Modern World-system: Capitalist Agriculture and the Origins of the European World-economy in the Sixteenth Century, Academic Press, New York.

Weiner, A. B. (1985). Inalienable wealth. American Ethnologist 12: 210-227.

Wood, M. (2000). Making connections: Relationships between international trade and glass beads from the Shashe-Limpopo area. South African Archaeological Society Goodwin Series 8: 78-90.

Wylie, A. (1985). The reaction against analogy. Advances in Archaeological Method and Theory 8: 63-111.

Yoffee, N. (2005). Myths of the Archaic State: Evolution of the Earliest Cities, States, and Civilizations, Cambridge University Press, Cambridge. 


\section{Bibliography of Recent Literature}

Antonites, A. (2014). Glass beads from Mutamba: Patterns of consumption in thirteenth-century southern Africa. Azania: Archaeological Research in Africa 49: 411-428.

Chirikure, S., Bandama, F., House, M., Moffett, A., Mukwende, T., and Pollard, M. (2016). Decisive evidence for multidirectional evolution of sociopolitical complexity in southern Africa. African Archaeological Review 33: 75-95.

Connah, G. (2001). African Civilizations: An Archaeological Perspective, Cambridge University Press, Cambridge.

Denbow, J., Klehm, C., and Dussubieux, L. (2015). The glass beads of Kaitsha'a and early Indian Ocean trade into the far interior of southern Africa. Antiquity 89: 361-377.

Dietler, M. (2010). Consumption. In Hicks, D., and Beaudry, M. (eds.), The Oxford Handbook of Material Culture Studies, Oxford University Press, Oxford, pp. 207-226.

Feinman, G. M. (2012). Circumscription theory and change: From determinism to mechanisms and parameters. Social Evolution \& History 11(2): 44-47.

Fleisher, J., and Wynne-Jones, S. (2010). Authorisation and the process of power: The view from African archaeology. Journal of World Prehistory 23: 177-193.

Labianca, O. S., and Scham, S. A. (2006). Connectivity in Antiquity: Globalization as Long-Term Historical Process, Approaches to Anthropological Archaeology, Equinox, Sheffield.

LaViolette, A. (2008). Swahili cosmopolitanism in Africa and the Indian Ocean world, AD 600-1500. Archaeologies 4(1): 24-49.

McIntosh, R. J. (2005). Ancient Middle Niger: Urbanism and the Self-Organizing Landscape, Cambridge University Press. Cambridge.

Mills, B. J. (2004). The establishment and defeat of hierarchy: Inalienable possessions and the history of collective prestige structures in the Pueblo Southwest. American Anthropologist 106: 238-251.

Monroe, J. C. (2013). Power and agency in precolonial African states. Annual Review of Anthropology 42: 17-35.

Ogundiran, A. (2002). Of small things remembered: Beads, cowries, and cultural translations of the Atlantic experience in Yorubaland. International Journal of African Historical Studies 35: 427-457.

Pikirayi, I. (2017). Trade, globalisation and the archaic state in southern Africa. Journal of Southern African Studies 43: 879 -893.

Price, T. D., and Feinman, G. M. (2012). Social inequality and the evolution of human social organization. In Price, T. D., and Feinman, G. M. (eds.), Pathways to Power: New Perspectives on the Emergence of Social Inequality, Springer, New York, pp. 1-14.

Schortman, E. M., and Urban, P. A. (2004). Modeling the roles of craft production in ancient political economies. Journal of Archaeological Research 12: 185-226.

Publisher's Note Springer Nature remains neutral with regard to jurisdictional claims in published maps and institutional affiliations. 